\title{
Argument structure and functional projections in Old Hungarian verbal gerunds*
}

\section{Éva Dékány}

Research Institute for Linguistics, Hungarian Academy of Sciences, Budapest dekany.eva@nytud.mta.hu

\begin{abstract}
This paper seeks to give a syntactic analysis of Old Hungarian verbal gerunds. I take the "mixed projection" approach to nominalizations (Bresnan 1997; Borsley \& Kornfilt 2000; Alexiadou 2001, among others), whereby the extended VP is embedded under nominal functional categories. I argue that in the verbal part of the gerund there is solid evidence for AspP/PredP dominating VoiceP, but there is no conclusive evidence for a TP being projected. I suggest that the object of the gerundival verb may undergo scrambling to a position above negation, while the subject becomes a derived possessor on the surface. I propose that these gerunds do not contain a nominalizer (see Alexiadou 2005; Alexiadou et al. 2010b; 2011 for this possibility); the extended vP is embedded directly under the nominal functional head Poss.
\end{abstract}

Keywords: gerund; mixed projection; nominalization; possessor; Old Hungarian

\section{Introduction}

Old Hungarian (896-1526 A.D.) features a wide variety of non-finite verb forms: in addition to an infinitive, it also has several types of adjectival and adverbial participles as well as two types of gerunds. This paper focuses on

\footnotetext{
* This research was funded by the "Hungarian generative diachronic syntax" project (OTKA 78074), the "Comprehensive grammar resources - Hungarian" project (OTKA NK 100804), and a postdoctoral grant of the Hungarian Academy of Sciences. Selected aspects of this research project were presented to academic audiences at the 2013 Olomouc Linguistics Colloquium, the 11th International Conference on the Structure of Hungarian, and A Nyelvtörténeti Kutatások Újabb Eredményei VIII. I thank the participants of these events as well as the two anonymous reviewers for useful feedback. Potential errors of fact and interpretation are my responsibility.
} 
the syntactic structure of one of the Old Hungarian gerunds: that marked by the suffix $-t(1){ }^{1}$

(1) haromźèr tagać-meǵ [èngem-èt efmèr-t-ed-èt]

three.times deny-PRT I-ACC know-t-2SG-ACC ${ }^{2}$

'you deny your knowing me three times'

(Munich C. 81 va)

The theoretical basis of the analysis is the "mixed projection" approach to gerunds taken in Bresnan (1997); Borsley \& Kornfilt (2000); Alexiadou (2001 et seq.); Panagiotidis \& Grohmann (2009), among others. It is well known that the internal syntax of gerunds is verbal but their distribution in the clause is nominal. The mixed projection approach holds that this pattern arises because a verb is associated "with one or more nominal functional categories instead of or in addition to the normal verbal functional categories, appearing above any verbal functional categories" (Borsley \& Kornfilt 2000, 102). This can be schematically represented as in (2).

$(2)$

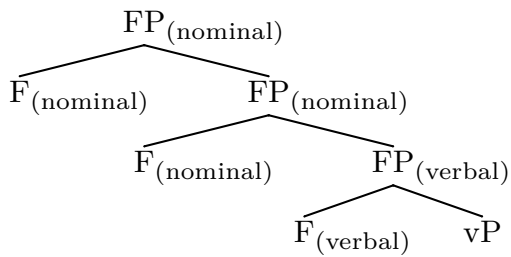

The picture that emerges from the "mixed projection" literature is that there is considerable cross-linguistic and intra-linguistic variation in the amount of both verbal and nominal structure in gerunds. The size of the extended verbal projection ranges from VP to vP, AspP, TP, and CP (Pires 2001; 2006; Panagiotidis \& Grohmann 2009; Alexiadou et al. 2010b, among

${ }^{1}$ The other gerund takes the non-finite suffix -ás/-és. I cannot enter into a discussion of -ás/-és gerunds here. The interested reader is referred to Tóth (2011b) for some remarks.

2 The paper contains the following abbreviations: ACC: accusative, ADE: adessive case, ADV.PART: adverbial participle, ALL: allative case, C.: Codex, CAU: causalfinal case, COND: conditional, DAT: dative, DEL: delative case, ELA: elative case, ILL: illative case, IMP: imperative, INE: inessive case, INF: infinitive, INS: instrumental case, LAT: lative case, NMZ: nominalizer, PASS: passive, PL: plural, POSS: possessedness marker, PRS.PART: present participle, PST: past, PRS.PART: present participle, PRT: verbal particle, r: recto (front side of a leaf of paper in a codex; two-column texts are divided into "a" and "b" columns), SG: singular, sUB: sublative case, SUP: superessive case, TER: terminative case, v: verso (back side of a leaf of paper in a codex; two-column texts are divided into "a" and "b" columns). 
many others). The amount of nominal functional projections is also subject to variation: some gerunds contain $\mathrm{nP}$, ClassP, NumP as well as DP, while in others the extended $\mathrm{vP}$ is embedded directly under a $\mathrm{D}$ head without lower nominal projections being present in the structure (Alexiadou et al. 2010b). Alexiadou et al. (2010a; 2011) argue that English Poss-ing gerunds (verbal gerunds), for instance, have numerous verbal functional projections but very few nominal functional projections (in fact, only one), as in (3), while English -ing of gerunds (nominal gerunds) have little verbal structure but a more elaborate range of nominal functional layers, as in (4). (See also Borsley \& Kornfilt 2000 for examples of cross-linguistic variation in the range of nominal and verbal layers in mixed projections.)

(3) $[\mathrm{DP}[$ AspectP $[$ VoiceP $[\mathrm{vP} \cdots$

English Poss-ing gerunds

(4) $[\mathrm{DP}[($ NumberP $)[$ ClassifierP $[\mathrm{nP}[$ VoiceP $[\mathrm{vP} \ldots$

English -ing of gerunds

The aim of this paper is to investigate the amount of verbal and nominal functional structure present in Old Hungarian - $t$ gerunds, and to examine how the subject of these gerunds is case-licensed. The majority of the data in the paper come from the Old Hungarian codices (late 14th to early 16th century), while the rest come from personal letters written in the early 16 th century. ${ }^{3}$

The paper is organized as follows. In section 2 I give a brief background to the different uses of the - $t$ morpheme in Old Hungarian, and in section 3 I demonstrate that the $-t$ gerund is a genuine "mixed" category showing both verbal and nominal properties. In section 4 I give critical discussion of a previous attempt by Tóth (2011b) to account for the syntax of $-t$ gerunds. I put forth my own proposal in section 5 . To anticipate the claims, I am going to propose that $-t$ gerunds project up to at least AspP, they have a fair amount of nominal functional structure, and the subject of the gerundival verb raises to the nominal layers in order to be case-licensed. My conclusions are in section 6 .

${ }^{3}$ In the data collection I have heavily relied on the examples presented in previous descriptive works, especially Simonyi (1907) and Károly (1956), as well as on the examples of Tóth (2011b). I have also used the corpus query tool of the "Hungarian generative diachronic syntax" project (OTKA-78074) available at http://corpus.nytud.hu/hgds-dev/hu-search.html. All data collected from these sources have been checked in the transcriptions listed under Primary sources. 


\section{Preliminary remarks on the $-t$ suffix and the history of gerunds}

The - $t$ morpheme in Old Hungarian appears in a variety contexts. Firstly, it serves as the gerundival ending.

(5) $[$ A zen-an fec-t-e-t $] \quad$ zenued-e

the hay-SUP lie-t-3SG-ACC suffer-PST.3SG

'he suffered his laying on the hay'

(Apor C. 130)

Secondly, $-t$ is also the suffix of the present perfect (6). The past perfect is formed from the present perfect with the help of an auxiliary (the past tense of the copula), thus - $t$ appears in the past perfect, too (7).

(6) meǵ lèl-t-em èn iuh-om-at ki èl vèzet-uala

PRT find-PERF-1SG I sheep-1SG-ACC that PRT lost-be.PST

'I have found my sheep which was lost'

(Munich C. $74 \mathrm{ra}$ )

(7) Es meg èmlèkez-ec Pèter a3 iǵè-rol kit mond-ot vala

and PRT remember-PST.3SG Peter the words-about that say-PERF.3SG was

neki $\quad \mathrm{i}^{\mathrm{c}}$

to.him Jesus

'and Peter remembered the words that Jesus had said to him' (Munich C. 52 ra)

É. Kiss (2014a) argues that the use of $-t$ as a gerundive ending was primary, and it was speakers of Proto-Hungarian that reanalyzed it as a perfectivity marker. In Early Old Hungarian the $-t$ gerund and the $-t$ present perfect ending lived side by side. The $-t$ perfectivity marker, in turn, was reanalyzed as a past tense suffix by the end of the Old Hungarian period, so Late Old Hungarian saw the co-existence of the $-t$ gerund and the $-t$ past tense marker. In present day Hungarian - $t$ lives on as a past tense suffix only.

(8) a. tegnap meg-lel-t-em a juh-om-at

yesterday PRT-find-PST-1SG the sheep-1SG-ACC

'I found my sheep yesterday'

b. tegnap mond-t-a, hogy ...

yesterday say-PST-3SG that

'he said yesterday that ...'

Complex tenses like the present and past perfect have been lost completely. The gerund has also been lost as a productive nominalization, and only a few (near-)lexicalized forms remain (see Radics 1992); most of them are 
frozen in the 3SG form. Some examples that still allow non-3SG subjects are shown in (9).

(9) jár-t-om-ban, hol-t-om-ig, tud-t-uk-kal walk-t-1SG-INE death-t-1SG-till know-t-3PL-INS

'during my going about, until my dying, with their knowledge' (lit. 'knowing')

Some gerunds have been lexicalized as nouns (10), postpositions (11), and adverbs (12).
(10) nap-kel-t-e
sun-rise-t-POSS
'sunrise'

\author{
(11) men-t-é-n \\ go-t-POSS-SUP \\ 'along'
}

(12) jár-t-á-nyi erő

walk-t-Poss-ful strength

'strength enough to walk' (lit. 'walkingful strength')

In addition to using it in gerunds, in the present perfect, and later in the simple past tense, Old Hungarian also employs the $-t$ suffix in adjectival and adverbial participles. The $-t$ adverbial participle has either a referentially independent, morphologically unmarked subject (13), or a covert subject coreferent with a matrix argument (14). This participle expresses temporal simultaneity with the matrix predicate and obligatorily agrees with its overt or covert subject. The - $t$ of the adverbial participle is regularly, though not exclusively, written as $-t t$.

(13) [O ke $\cdot$ az aiton - ki men-ètt-e] lata otèt mas leań he thus the door-SUP out go-t-3SG see-PST.3SG him another maid 'when he was going out the door, another maid saw him' (Munich C. $33 \mathrm{vb}$ )

(14) Lat-a Leui- $\mathrm{t}_{i}$ alfeus fia-t [a $\cdot$ vam-on $\quad \mathrm{PRO}_{i}$ ìl-ett-è $]$ see-PST.3SG Levi-ACC Alphaeus son-ACC the custom-SUP sit-t-3SG 'he saw Levi the son of Alphaeus sitting at the receipt of custom' (Munich C. 37 va)

Adjectival participles with - $t$ contain a "gap" in the position of the internal argument (these are often erroneously called perfect participles), or the possessor of the internal argument, or the object. For a detailed exposition of these types of participles, see Dékány (2014) and Bácskai-Atkári \& Dékány (2014). 
(15) [fewld-re es-ewt'] wag-yok ground-suB fall-t be-1SG

'I am fallen to the ground'

(16) eg $\left[\left[\mathrm{PRO}_{(\text {possessor })^{i}} \mathrm{kez}^{-\mathrm{e}}\right] \quad\right.$ meg aź-ot $] \quad$ èmber $_{i}$

a hand-POSS.3SG PRT wither-PART man

'a man that had a withered hand'

(Munich C. 38 ra)

(17) [zent Mathe yr-t-a] kenyw-ee-nek heeted reez-ee-ben.

saint Matthew write-PART-3SG book-POSS-DAT seventh chapter-POSS-INE

'(in) chapter seven of Saint Matthew'

(Érdy C. 131)

The - $t$ gerund can be distinguished from the other Old Hungarian nonfinites with $-t$ on the basis of its distribution in the clause. Unlike verbs with the present perfect suffix or the past tense suffix, or adjectival and adverbial participles, the $-t$ gerund appears in the positions where ordinary nominals do: as arguments of verbs, as possessors, and (when they bear some oblique case) as adverbial adjuncts. I will discuss the nominal distribution of $-t$ gerunds in more detail in the next section.

Finally, in Old Hungarian - $t$ also serves as a simple deverbal nominalizer (18).

(18) a. el-et

live-t

'life'

(Festetics C. 134 r)

b. acar-at

want-t

'will'

(Guary C. 131)

c. felel-et

answer-t

'answer'

(Jókai C. 10)

d. kyfert-ett

haunt/tempt-t

'temptation, ghost'

(Jókai C. 50)

The simple - $t$ deverbal nominal, as opposed to the $-t$ gerund, may appear without possessive morphology, and it cannot take Accusative objects, adverbial modifiers, or clause negation. 


\section{Nominal and clausal properties of the Old Hungarian - $t$ gerund}

\subsection{Nominal external distribution}

Old Hungarian gerunds with - $t$ have the same distribution as nouns. They can appear in argument positions of verbs (as subjects, bearing the morphologically unmarked Nominative case (19), or as objects, bearing Accusative case (20)) and as nominal arguments (i.e., as possessors, bearing Dative case (21)).

(19) mert yo volt tee-nek-ed [en na-lam le-tt-ód] because good was you-DAT-2SG I ADE-1SG be-t-2SG

'because your being at my place was good for you'

(Érdy C. 510)

(20) Ne zegÿenl-etek [alamÿzna-ert ment-ett-ek-et]

not be.ashamed-IMP.2PL alms-CAU go-t-2PL-ACC

'do not be ashamed of your going for alms'

(Jókai C. 81-82)

(21) [poncius pilatus Iudea-ban birolkot-t-a-nac] idè-ie-bèn pontius pilate Iudea-INE govern-t-POSS-DAT time-POSS-INE

'during the reign of Pontius Pilate in Iudea'

(Munich C. 56 vb)

Just like nouns, gerunds can also bear oblique cases. Observe the Inessive ('in'), the Sublative ('onto'), and the Causal-final ('for') marked gerunds in (22) through (24). Gerunds with oblique case marking serve as adverbs of state/manner, time, and cause.

(22) [fel-t-ec-bèn] iuolt-è- $n^{\mathrm{c}}$

afraid-t-3PL-INE shout-PST-3PL

'they shouted in their fear'

(Munich C. $21 \mathrm{rb}$ )

(23) [minden-ok-nek lat-t-a-ra] az bodogh zÿz serelom-nekwl meg marad-a every-PL-DAT see-t-POSS-SUB the blessed virgin injury-without PRT stay-PST.3SG 'upon everyone seeing, the blessed virgin remained without any injuries'

(Lázár C. 34r)

(24) $\ddot{y}$ mad-lak theged-eth ... [attÿa isten-nek ÿoghÿa-ra il-th-ed-erth] worship-1SG you-1ACC father god-DAT right-SUB sit-t-2SG-CAU

'I worship you for your sitting on the Heavenly Father's right' (Pozsony C. 13v-14 r)

Not only do gerunds have the same distribution and case marking as nouns, but they also obligatorily bear the possessive morphology that possessed 
ordinary nouns do. Garden variety nouns that have a lexical possessor bear the possessedness marker $-j a /-j e /-a /-e .^{4}$

(25) morpheme order on regular nouns with a lexical possessor:

$\mathrm{N}>$ possessedness marker $>\mathrm{Pl}>$ case

(26) gonossag-nak zaw-a-ý-ra

evil-DAT word-POSS-PL-SUB

'on (hearing) words of evil'

(Festetics C. 33 v)

Regular nouns with a pronominal possessor feature an additional piece of morphology: they agree for the $\phi$-features of the possessor. This agreement appears between the plural marker and the case marker.

(27) morpheme order on regular nouns with a pronominal possessor: $\mathrm{N}>$ possessedness marker $>\mathrm{Pl}>$ possessive agreement $>$ case

(28) te menden ut-a-i-d-at

your every way-POSS-PL-2SG-ACC

'your every way'

(Vienna C. 143)

When the possessum does not bear plural marking, then the possessedness marker and the possessive agreement end up in adjacent positions. In this configuration the possessedness marker fuses with the possessive agreement if the agreement is first or second person. Observe that in (29) the agreement is not preceded by a possessedness marker.

(29) te 3erzet-ed-et

your order-2SG-ACC

'your order'

(Jókai C. 112)

The possessedness marker does not fuse with the agreement if the agreement is third person (Bartos 1999; Rebrus 2000). In the third person singular the agreement is phonologically zero, so in this case we only see the possessedness marker in the string of morphemes.

(30) az o zep orća-ÿa- $\emptyset$-th

the he beautiful face-POSS-3SG-ACC

'his beautiful face'

(Könyvecse 23 r)

${ }^{4}$ Alternative terms used in the English literature on Hungarian DPs include "belonging marker" (Mel'čuk 1973), "possessive suffix" (É. Kiss 2002; Csirmaz 2006), and "POSS morpheme" (Laczkó 2007). In Old Hungarian and in dialectal Modern Hungarian, the possessedness marker may also take the form $-i$ or $-y$. 
A - $t$ gerund with a lexical subject, like an ordinary noun with a lexical possessor, also features the $-j a /-j e /-a /-e$ possessedness marker.

(31) morpheme order on- $t$ gerunds with a lexical subject:

$\mathrm{V}>-t>$ possessedness marker $>$ case

(32) minden-ok-nek lat-t-a-ra

every-PL-DAT see-t-POSS-SUB

'upon everyone's seeing'

(Lázár C. 34 r)

A - $t$ gerund with a pronominal subject, just like a regular noun with a pronominal possessor, bears the additonal $\phi$-feature agreement. The $-t$ gerund, like complex event nominals in many languages, cannot be pluralized. As a result, the possessedness marker and the agreement marker always end up in adjacent positions, and they fuse if the agreement is first or second person.

(33) morpheme order on $-t$ gerunds with a 1st or 2nd person pronominal subject:

$\mathrm{V}>-t>$ possessive agreement $>$ case

(34) haromźèr taga-ć-meǵ [èngem-èt esmèr-t-ed-èt]

three.times deny-2SG-PRT I-ACC know-t-2SG-ACC

'you deny your knowing me three times'

(Munich C. 81 va)

(35) morpheme order on $-t$ gerunds with a $3^{\text {rd }}$ person pronominal subject:

$\mathrm{V}>-t>$ possessedness marker $>$ agreement $>$ case

(36) nē rèmèll-ik-uala imarar $\quad[0$, nèk-i meg-iọ-t-è- $\boldsymbol{b}-\mathbf{t}]$

not hope-3PL-be.PST any.more he DAT-3SG PRT-come-t-POSS-3SG-ACC

'they were not hoping for her return any more'

(Vienna C. 38)

\subsection{Clausal characteristics}

As far as their internal structure is concerned, - $t$ gerunds have the characteristics of extended verbal projections. The $-t$ gerund preserves the full argument structure of the base verb (that is, it is a complex event nominal) and takes an Accusative marked object. ${ }^{5}$

${ }^{5}$ As with all types of Old Hungarian non-finite clauses, unmarked objects also occasionally appear. With - $t$ gerunds I am aware of just two examples, those in (i) (but more may come to light with the expansion of the normalized and morphologically tagged part of the Old Hungarian corpus at http://corpus.nytud.hu/hgds-dev/husearch.html): 


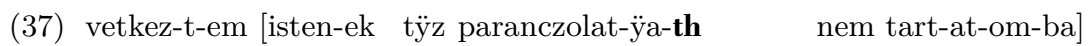
sin-PST-1SG God-DAT ten commandment-POSS-ACC not observe-t-1SG-INE 'I have sinned in not observing God's ten commandments'

(Virginia C. 3r)

Gerunds with - $t$ are modified by adverbs rather than adjectives (38), and they are also compatible with the clause negation nem (39).

(38) vetkez-t-em ... [mas ember iozag-a-t gonozol keuan-t-om-ba] sin-PST-1SG other man goods-POSS-ACC viciously wish-t-1SG-INE

'I have sinned in viciously wanting (to have) the goods of others' (Virginia C. 4 r)

(39) vetkez-t-em ... [en erzekenseg- $\ddot{y}-m-e t$ io-ra nem bÿr-t-om-ba] sin-PST-1SG I sensibility-POSS.PL-1SG-ACC good-SUB not hold-t-1SG-INE 'I have sinned in not using my sensibility for good'

(Virginia C. $2 \mathrm{v}$ )

Depending on how much verbal and nominal structure they have, gerunds are divided into two groups: verbal and nominal gerunds (see Abney 1987; Kim 2001; Moulton 2004; Alexiadou 2005; Alexiadou et al. 2010b, among many others). Nominal gerunds show more nominal properties: they are modified by adjectives, are incompatible with clause negation, and the verb's object cannot receive Accusative case (e.g., English the enemy's quick destroying of the city). Verbal gerunds, on the other hand, show

(i) a. hall-ott-ac [o-nèk-i è ièlèn $\int e g$ te-t-è- $\left.\emptyset-t\right]$

hear-PST-3PL he-DAT-3SG this deed do-t-POSS-3SG-ACC 'they heard of his doing this deed'

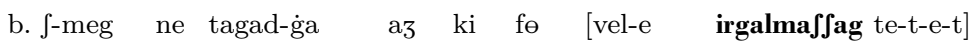
and-PRT not deny-IMP.3SG that who chief with-3SG mercy do-t-3SG-ACC 'and that who is chief (power) should not deny his being mercyful to him'

(Birk C. 3a)

Unmarked objects in Old Hungarian non-finites only occur in preverbal position; this is a fossil from the Proto-Hungarian period and does not mean that the verb is unable to assign Accusative case to its object. Proto-Hungarian was an SOV language with an unmarked object (É. Kiss 2013; 2014c). By the Old Hungarian period the word order had already shifted to SVO (or Topic Focus V X*) and object marking became obligatory in finite clauses. However, certain types of non-finite clauses still featured a strictly verb-final order, and the lack of Accusative case on preverbal objects of non-finites also remained a possibility (albeit Accusative marking prevailed on these objects as well). See Radics (1992) and especially É. Kiss (2013) on the original OV order, and É. Kiss (2013) and Bácskai-Atkári \& Dékány (2014) on the remnants of Proto-Hungarian syntax in Old Hungarian non-finites. In Old Hungarian postverbal objects of non-finites, including - $t$ gerunds, already obligatorily bear Accusative case, while in Modern Hungarian both pre- and postverbal objects do so. 
fewer nominal and more verbal properties: they are modified by adverbs, are compatible with negation, and the verb's object receives Accusative case (e.g., English the enemy's cruelly destroying the city). The general consensus of the literature is that this split can be traced back to a difference in the size of the extended verbal projection: nominal gerunds embed a smaller verbal structure, while verbal gerunds embed a bigger clausal structure. Given that $-t$ gerunds are compatible with negation, they are modified by adverbs, and their verb assigns Accusative case, we must conclude that they are verbal gerunds (see also Tóth 2011b).

Gerunds with - $t$ may have a covert subject that is coreferential with a main-clause argument (40). ${ }^{6}$

(40) tud-om, [alut-t-om] sem leszen

know-1SG sleep-t-1SG not will.be

'I know I will not have any sleep' (lit. 'I know my sleeping will not be') (Level 95)

They may also have a covert, non-coreferent subject.

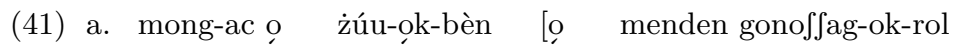

say-3PL they heart-3PL-INE they every sin-3PL-DEL

meg-èmlèkez-t-em-èt]

PRT-remember-t-1sG-ACC

'they say in their heart my remembering every evil deed of theirs'

(Vienna C. 189)

b. meg' nýt-odt-ad [bel mene-t-y-tt' te lakodalm-ad-ba]

PRT open-PST-2SG in go-t-POSS.3SG-ACC you nuptials-2SG-ILL

'you have opened (the possibility of) his going to your nuptials' (Festetics C. 387)

Finally, gerunds may also have an overt, non-coreferent subject (42). These subjects are marked exactly like possessors: they may be either Dative marked or morphologically unmarked. The choice between the two types of markings is optional on possessors, and it also appears to be optional on gerundival subjects.

(42) a. Mōd-a o-nèk-i $\quad i^{\text {c }}$ Igen akar-om [o-nèk-i

say-PST.3SG he-DAT-3SG Jesus thus want-1SG he-DAT-3SG

marat-t-a-t] miǵlen iọ-uoc

stay-t-3SG-ACC until come-1SG

'Jesus said to him: I want his staying this way until I come back'

(Munich C. $108 \mathrm{rb}$ )

${ }^{6}$ I take the coreferential null subject to be a pro-dropped pro, while Tóth (2011b) suggests that this subject is a controlled pro. See section 5.5 for discussion. 
b. mond-a nek-i iesus iǵ akar-am ['́v marat-t-a-t] : mig say-PST.3SG DAT-3SG Jesus thus want-1SG he stay-t-3SG-ACC until meg io-iek PRT come-1SG

'Jesus said to him: I want his staying this way until I come back'

(Döbrentei C. 137 v)

\subsection{Interim summary}

Old Hungarian - $t$ gerunds are genuine "mixed projections". They have the internal structure of extended verbal projections: the full argument structure of the verb is preserved, the verb assigns Accusative case to the object, and they can be modified by clause negation and adverbs. Their subject, however, bears the morphological marking of possessors, and $-t$ gerunds have the distribution of nominals: they appear in argument positions and with an oblique case in adjunct positions, too. A further nominal property of theirs is that the nominalized verb is morphologically marked like a possessum.

\section{Previous work on Old Hungarian verbal gerunds}

As - $t$ gerunds obligatorily bear possessive morphology, the functional projections related to possession must be present in their syntactic structure. In this section I first discuss the nature and hierarchical order of these functional projections. Then I turn to Tóth's analysis of Old Hungarian gerunds.

\subsection{Possessive structure in Old Hungarian noun phrases}

The structure of the Modern Hungarian possessive construction has attracted significant interest (see Szabolcsi 1994; Laczkó 1995; den Dikken 1999; Bartos 2000; É. Kiss 2002; Dékány to appear, among others). The structure of Old Hungarian possessives is very similar to that of Modern Hungarian possessives; the only significant difference is the position of Dative possessors (as discussed by Egedi 2014a;b, these used to be lower and had a more flexible distribution than today).

As we have seen before, ordinary possessed nouns bear the possessedness marker $-j a /-j e /-a /-e$, the plural marker (if the possessum is plu- 
ral), the possessive agreement (if the possessor is pronominal), and a case marker.

(43) en-nek-em menden bin-e-i-m-et

I-DAT-1SG every sin-POSS-PL-1SG-ACC

'all my sins'

(Peer C. $100 \mathrm{v}$ )

Bartos (2000) argues that the possessedness marker is the head of a low PossP, the plural marker heads NumP, and the agreement marker projects an AgrP above NumP (44).

(44) [DP D [AgrP Agr [NumP Num [PossP Poss NP ]]]]

Morphologically unmarked pronominal possessors follow the definite article, while unmarked lexical possessors do not co-occur with the article.

(45) a. az tẃ neu-etek

the you(pl) name-POss.2SG

'your name'

(Könyvecse $2 \mathrm{r}$ )

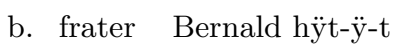

brother Bernald faith-POss.3SG-ACC

'brother Bernald's faith'

(Jókai C. 120)

It is uncontroversial that unmarked pronominal possessors are in spec, AgrP (Bartos 1999; É. Kiss 2002). Unmarked lexical possessors are taken to be either in the same position as unmarked pronominal possessors (Szabolcsi 1994; Bartos 1999) ${ }^{7}$ or to be higher, in spec DP (É. Kiss 2002). For ease of exposition, I will take both unmarked pronominal and unmarked lexical possessors to be in spec AgrP.

Dative marked possessors in Old Hungarian do not co-occur with the definite article, but they may co-occur with and precede the unmarked possessor (provided the former is a lexical possessor and the latter is a coreferent pronoun).

(46) Iwdÿth Azzoń-nak o Końv-e

Judith lady-DAT she book-POss.3SG

'Lady Judith's book' (lit. 'Lady Judith's her book') (Székelyudvarhely C. 50 v)

\footnotetext{
${ }^{7}$ Bartos argues that the determiner of the possessor undergoes incorporation into the D of the possessum (see especially the discussion in Bartos 1999, 107-108). This detail need not concern us here.
} 
As the unmarked possessor is in spec AgrP, the Dative marked possessor must be higher than this. Egedi (2013; 2014a;b) argues that Old Hungarian Dative possessors are in the specifier of DP. The structure of Old Hungarian possessive DPs is thus as in (47).

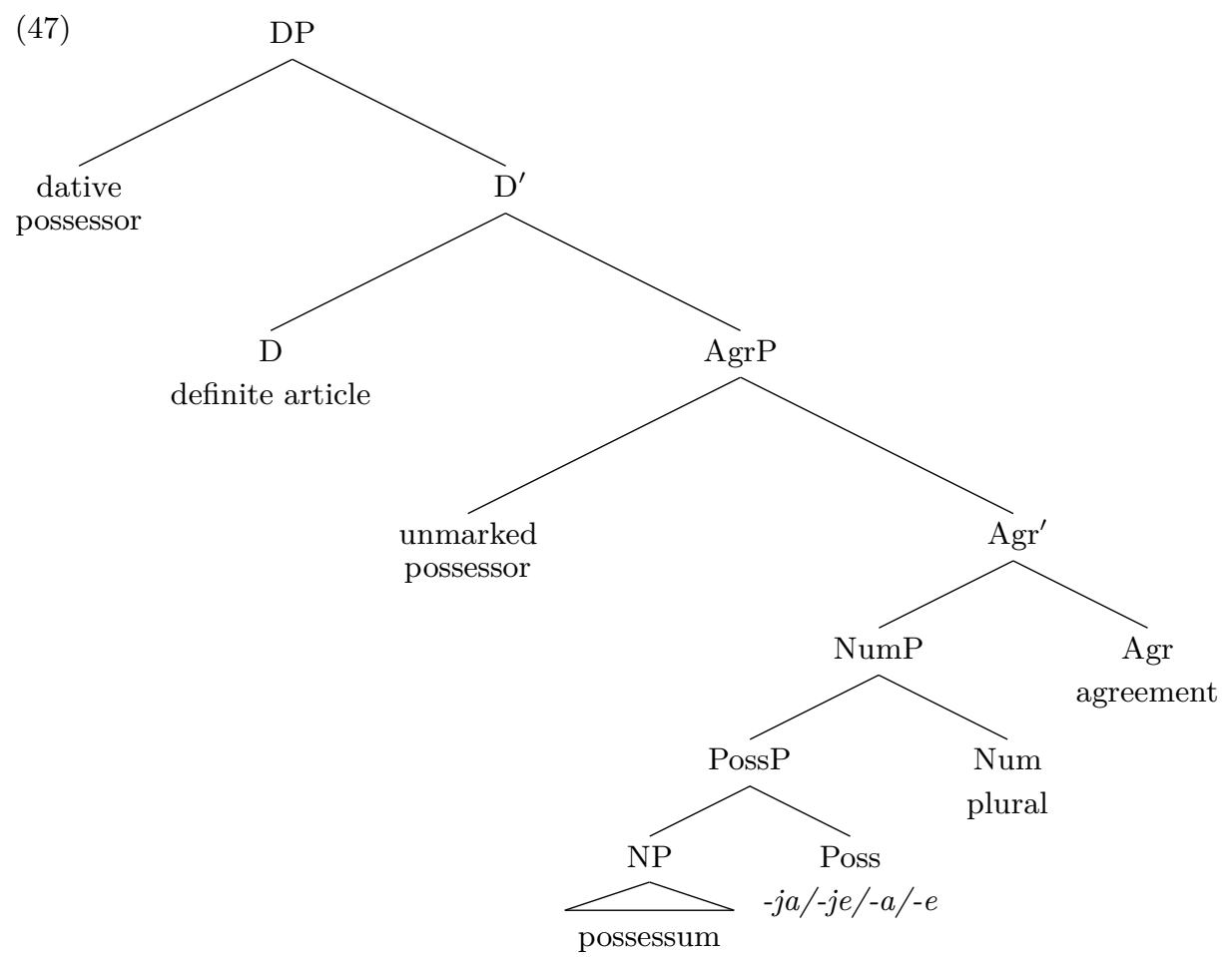

\subsection{Tóth's (2011) analysis}

Since Old Hungarian gerunds are morphologically marked like possessive structures, Tóth (2011b) assumes that they have the structure of possessed nominals; they contain a possessum and a possessor. As for the position of possessors, she follows the proposal of den Dikken (1999). Den Dikken argues that possessors (in Hungarian) are syntactically PPs headed by a Dative preposition. The reason why possessors may be unmarked or Dative marked is that the Hungarian Dative $\mathrm{P}$ has two morphological alternants: the overt $-n a k /$ nek $\mathrm{P}$ and a null allomorph $\mathrm{P}_{0}(48)$.

(48) $\left[\mathrm{PP} \mathrm{P}_{0 / \text { Dat }} \mathrm{DP}\right]$

the structure of the possessor 
The PP projected by the possessor is merged as the complement of the possessed noun.

(49) $\left[\mathrm{N}\left(\right.\right.$ possessum) $\left[\mathrm{PP} \mathrm{P}_{0 / \text { Dat }}\right.$ DP $\left.]\right]$

the core structure of possessive nominals

Combining the extended NP in (47) with den Dikken's proposal in (49) yields (50). Tóth argues that this is the structure of Old Hungarian gerunds.

(50) [DP D [AgrP Agr [PossP Poss [NP N [PP $\mathrm{P}_{0 / \text { Dat }}$ DP ] ] ]]]

For Tóth, there are two crucial differences between garden variety possessed nouns and $-t$ gerunds: gerunds contain a NominalizerP (spelled out by $-t$ ) rather than an ordinary $\mathrm{N}$, and in gerunds the complement of the $\mathrm{P}_{0 / \text { Dat }}$ head is a TP rather than a DP. ${ }^{8}$

(51) ordinary possessives



(52) gerunds

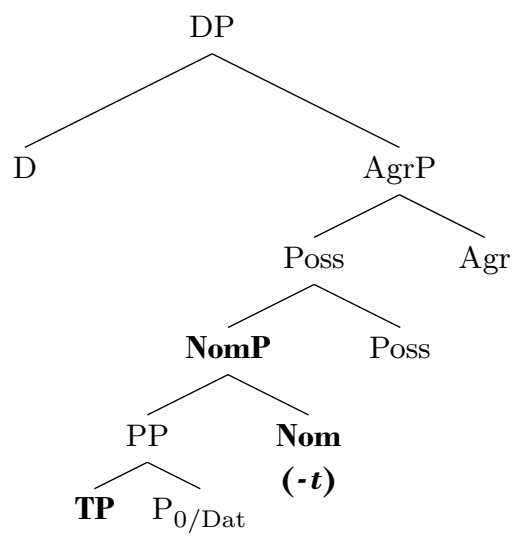

Tóth suggests that gerunds with a coreferential subject such as (53) have a controlled pro subject (54). ${ }^{9}$

${ }^{8}$ In addition, ordinary possessed nouns may be pluralized, hence they contain a NumP, while gerunds are never pluralized, so Tóth would probably assume that NumP is not projected in them (but she does not discuss this explicitly). I leave out NumP from (51) for expository purposes.

${ }^{9}$ For this Old Hungarian example, Tóth (2011b) does not provide the source and uses modern Hungarian orthography. 
(53) ne szégyel-d [engem-et ismer-t-ed-et]

not be.ashamed-IMP.2SG I-ACC know-t-2SG-ACC

'do not be ashamed of your knowing me'

(Tóth 2011b, ex. (19a))

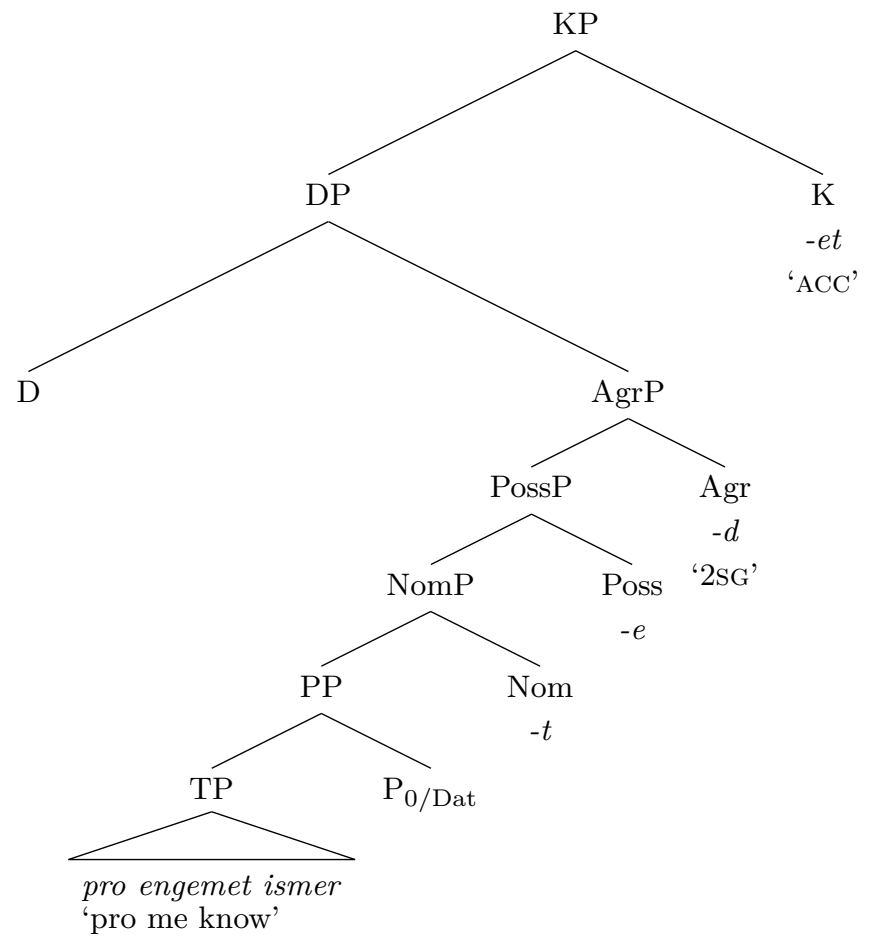

In the previous section we have seen that $-t$ gerunds may also have a non-coreferent overt subject. These subjects are either morphologically unmarked or Dative marked. Tóth proposes that the overt subject is in spec TP, but the non-finite T cannot assign structural case. To circumvent this case problem the subject gets inherent Nominative or Dative case. (56) is her analysis of such an example. ${ }^{10}$

${ }^{10}$ Note that this example, in fact, has a coreferential subject: the overt DP io lan 'good maid' is the subject of the imperative, and the gerund's subject is coreferent with this DP. (55) is thus much like (53) (modulo the fact that in (53) the main clause subject is pro and in (55) the main clause subject is a lexical noun). This is particularly clear if we consider this example in context:

(i) mond-a Ne altall-a io lan bè-mē-t-è-t èn vr-am-hoz hog say-PST.3SG not fear-IMP.3sG good maid in-go-t-POSS-ACC I lord-1sG-TO that 
(55) Ne altall-a io lan bè-mē-t-è-t

not fear-IMP.3SG good maid in-go-t-POSS-ACC

'Let not the good maid fear her going in'

(Vienna C. 36)

(56)

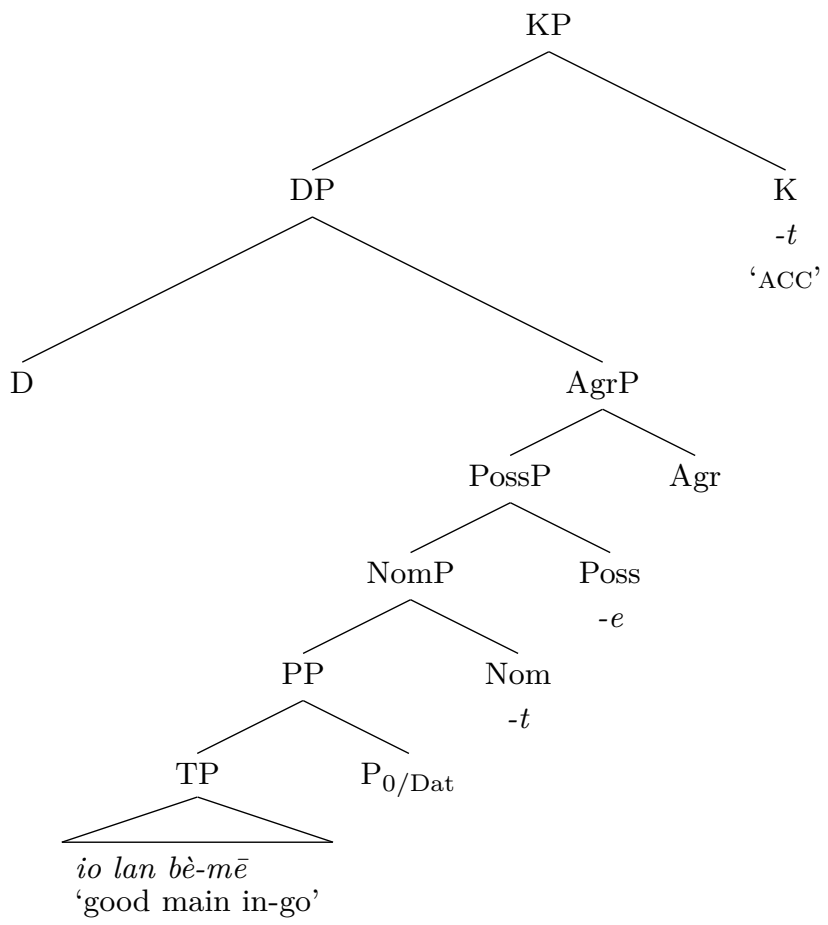

While I agree with Tóth that - $t$ gerunds comprise functional projections of the extended $\mathrm{vP}$ dominated by nominal functional projections, I also believe that there is room for some alternative analysis here. The first reason to revisit Tóth's analysis has to do with the NomP $>\mathrm{PP}>\mathrm{TP}$ functional hierarchy. Recall that in den Dikken's analysis, the possessor is embedded in a PP, and the PP itself is the complement of the possessum.

(57) $\left[\mathrm{N}\right.$ (possessum) $\left.\left[\mathrm{PP} \mathrm{P}_{0 / \text { Dat }} \mathrm{DP}\right]\right]$

tiztel-tè $\int-\dot{e} \quad$ o orca-ia èlot

honour-PASS-3SG he face-POSS.3SG in.front.of

'Let not the good maid fear her going in to my lord, that she may be honoured before his face.'

(Vienna C. 36)

This, however, does not influence the main point of the analysis, namely that the unmarked or Dative marked DP is in spec TP. 
Now in Tóth's analysis, the PP takes a TP complement, and the PP itself is the complement of the nominalizing head Nom.

(58) [.NomP Nom:- $\left.t\left[\mathrm{PP}_{0} \mathrm{P}_{0 / \text { Dat }} \mathrm{TP}\right]\right]$

Given the structure in (57), this means that Tóth analyzes the TP as the possessor, and the nominalizing suffix as the possessum. There are various considerations, however, that militate against this analysis. Firstly, as Baker (2005) points out, the gerundival nominalizing affix is a functional rather than a lexical head, and this would make it very difficult to treat it as the possessum. Secondly, the morphological evidence shows that the possessor in - $t$ gerunds is the subject of the verb phrase rather than the extended verbal projection (TP). Consider the following examples with an overt subject.

(59) meg-akar-ia ṅomoreit-ani [èn ièlèn vol-t-om-ban]

PRT-want-3SG cripple-INF I present be-t-1SG-INE

'he wants to cripple him in my presence' (lit. 'in my present being') (Vienna C. 64)

(60) hall-ott-ac [o-nèk-i è ièlè $\int e g$ te-t-è- $\left.\mathbf{b}-\mathbf{t}\right]$

hear-PST-3PL he-DAT-3SG this deed do-t-POSS-3SG-ACC

'they heard of his doing this deed'

(Munich C. 98 vb)

In (59), the constituent that is morphosyntactically the possessor is the subject èn ' $\mathrm{I}$ ', because this is the morphologically unmarked element, and what is morphosyntactically the possessum is the verb $+-t$ unit vol-t, because this constituent bears the possessedness marker. Similarly in (60), the constituent that is morphosyntactically marked as the possessor is the subject o-nèk-i 'he-DAT-3SG', because this is the Dative marked element, and what is morphosyntactically the possessum is the verb $+-t$ unit $t e-t$, as this constituent hosts the possessedness marker. ${ }^{11}$

The NomP $>$ PP $>$ TP hierarchy raises some other problems, too. As for $\mathrm{PP}>\mathrm{TP}$, it is difficult to see what a $\mathrm{P}$ head would do on top of a clause (adpositions embed nominals). The NomP $>\mathrm{PP}$ hierarchy is equally problematic: while deverbal nominals and deadjectival nominals are widely known, nouns derived from PPs (what we could call "deadpositional nominals") do not occur (recall that $-t$ in the Nom head is a nominalizer). If anything, the clause should be first nominalized and then embedded un-

${ }^{11}$ Compare also the fairly similar English Poss-ing gerunds: it is clear that the subject (rather than the nominalized verbal projection) is the possessor: the enemy's destroying the city. 
der a $\mathrm{PP}(\mathrm{PP}>\mathrm{NomP}>\mathrm{TP})$. Last but not least, it is unclear how it could be ensured that in the sequence $\operatorname{AgrP}>\operatorname{PossP}>\mathrm{NomP}>\mathrm{PP}_{0 / \text { Dat }}>\mathrm{TP}$ the exponent of the $\mathrm{P}_{0 / \text { Dat }}$ head ends up on the TP's subject (producing the morphologically unmarked or Dative marked DP), while the exponents of the other functional heads Nom, Poss, and Agr end up on the verb (see example (60), for instance).

The second reason to rethink the analysis is that the fact that $-t$ gerunds must bear possessive morphology does not follow from the account. Ordinary nouns and other types of deverbal nominalizations (e.g., -ás/-és gerunds) can be unpossessed.

(61) a. ez końv́ felol

this book about

'about this book' (Székelyudvarhely C. 51 r)

b. megh ÿr-t-am ez końv-et

PRT write-PST-1SG this book-ACC

'I have written this book'

(Székelyudvarhely C. 51 r)

(62) Az ysten nep-e-th $\quad$... hala ad-af-ra ynt-y az profeta

the god people-POSS-ACC thanks give-NMZ-SUB warn-3sG the prophet

'the prophet warns God's people to give thanks'

(Apor C. 12)

It is not clear why - $t$ gerunds should be different: in principle, the extended vP should be nominalizable without the merger of a PossP on top of NomP.

\section{The structure of Old Hungarian verbal gerunds}

As already mentioned before, - $t$ gerunds are verbal gerunds and are very similar to English Poss-ing gerunds: their subject is marked as a possessor, Accusative case is available for the object, modification is adverbial rather than adjectival, and negation is possible. It is a matter of some debate in the literature how much verbal structure Poss-ing gerunds have. Moulton (2004) argues that only a vP is projected, while Alexiadou et al. (2010a) suggest that the Aspect layer is also present. As for Old Hungarian - $t$ gerunds, Tóth (2011b) assumes that they project all the way up to TP. In the next subsections I will investigate the amount of verbal functional structure in - $t$ gerunds by examining the functional elements that can appear and the surface positions of the verb's arguments. I will conclude that there is no clear evidence for a TP in - $t$ gerunds, but there is good evidence for certain functional projection between $\mathrm{vP}$ and $\mathrm{TP}$. 


\subsection{Functional elements and their projections in $-t$ gerunds}

Gerunds with - $t$ admit the following types of functional elements: verbal particles, negation, and adverbial modifiers. Adverbial modifiers include manner adverbs (63), locative adverbs (64), and adverbial participles (64).

(63) vetkez-t-em ... [mas ember iozag-a-t gonozol keuan-t-om-ba]

sin-PST-1SG other man goods-POSS-ACC viciously wish-t-1sG-INE

'I have sinned in viciously wanting (to have) the goods of others' (Virginia C. 4 r)

(64) kic zèrèt-ic [Sinagoga-i-oc-ban es [AdvPart vća-c zeg-e-n

who like-3PL synagouge-POSS-3PL-INE and street-PL corner-POSS-SUP

al-uā] imatkoz-t-oc-at]

stand-ADV.PART pray-t-3PL-ACC

'who like their (own) praying in their synagouge and standing on street corners'

(Munich C. 12 ra)

The analysis of adverbial modification has sparkled a lively debate in the literature, and the adjunct versus specifier controversy has proved not to be easy to solve on empirical grounds. On the adjunct analysis of adverbs, (63) does not show much about the functional structure of $-t$ gerunds: manner adverbs are low adverbs adjoined to $\mathrm{vP}$, a category that is projected in verbal gerunds in everyone's analysis. On the specifier analysis of adverbs, however, manner adverbs diagnose the presence of a low functional head above vP. Cinque (1999) argues that manner adverbs are in the specifier of VoiceP. If this analysis is on the right track, then (63) provides evidence for $-t$ gerunds projecting up to at least VoiceP. ${ }^{12}$

While adverbs may be analyzed as adjuncts, clause negation is standardly taken to be introduced by a functional projection in the IP-domain. (65) and other examples with negation thus provide evidence that $-t$ gerunds project beyond $\mathrm{vP}$.

(65) vadol-om bwnws-nek magam-at [nÿolcz bodogsa-got

accuse-1SG guilty-DAT self.1SG-ACC eight beatitude-ACC

nem keuan-t-om-ba]

not wish-t-1SG-INE

'I accuse myself of being guilty of not wishing the eight beatitudes' (Virginia C. 6 v)

12 Alexiadou et al. (2011) and Alexiadou (2013) argue that low adverbs are licensed by a slightly higher projection, AspP. Below I will present adverb-independent evidence for AspP in Old Hungarian gerunds. 
Further evidence for structure beyond $\mathrm{vP}$ is provided by the preverbal position of verbal particles (both directionals and the purely perfectivizing meg).

(66) a. meg-bā-t-ac [èl-fordol-t-ok-at o

PRT-regret-PST.3PL away-turn-t-3PL-ACC they

iftèn-èk-nc̣ zolǵalat't'-a-tol]

god-3PL-DAT service-POSS-DEL

'they regretted turning away from serving their God'

(Vienna C. 19)

b. nē rèmèll-ik-uala imar [o nèki meg-io-t-è-t $]$

not hope-3PL-be.PST any.more he DAT-3SG prt-come-t-POSS-ACC

'they were not hoping for her return any more'

(Vienna C. 38)

Verbal particles in Hungarian belong to the group of so-called verbal modifiers (VMs), a group of heterogenous elements that share the same syntactic distribution in the clause. In both Old Hungarian and present-day Hungarian, VMs occupy the immediately preverbal position in neutral sentences, while in declaratives with negation or focus and in imperatives they are postverbal. The analysis of VMs is one of the most thorny problems of Hungarian syntax. While details of the analysis vary considerably, all are agreed that in their preverbal position VMs occupy the specifier of a functional projection within the IP-domain. É. Kiss (2002); Alberti (2004); Csirmaz (2006) identify this position as AspP, while (Csirmaz 2004; É. Kiss 2006b; Hegedűs submitted) take it to be PredP. I will follow their analyses here. The presence of verbal particles in the preverbal position thus diagnoses the presence of a functional projection above vP: either AspP or PredP. ${ }^{13} \mathrm{I}$ am not aware of any examples in which a verbal particle and negation co-occur, but (67) features iora, another type of VM, preceding negation. We can thus conclude that AspP/PredP dominates NegP. ${ }^{14}$

13 Csirmaz (2006) argues that the order of the two projections is AspP > PredP.

${ }^{14}$ For the sake of completeness, it has to be noted that there are also analyses that place VMs lower, into spec VP (Broekhuis \& Hegedüs 2009; Hegedüs 2013), and proposals that take the VM to raise higher, into spec TP (Surányi 2009a;b; É. Kiss 2011). I will argue later on that Old Hungarian - $t$ gerunds do not have a TP layer, so the VM in them cannot be in spec TP. The lack of TP in gerunds, however, is compatible with the view that in finite clauses VMs sit in spec TP. Surányi argues that VMs move to spec TP in two steps: first they move to an intermediate, low position (where they pseudo-incorporate into the verb), and raising to spec TP involves a second movement step. The following scenario is thus possible. In finite clauses the VM raises to spec TP in two steps. TP is not projected in gerunds, so in this case only the first movement (to the lower, intermediate position) can take place, and the VM stays in this position. 
(67) vetkez-t-em ... [en erzekenseg- $\ddot{y}$-m-et

sin-PST-1SG I sensibility-POSS.PL-1SG-ACC

io-ra nem bÿr-t-om-ba]

good-SUB not hold-t-1SG-INE

'I have sinned in not using my sensibility for good'

(Virginia C. 2 v)

To summarize the discussion so far, the functional elements in - $t$ gerunds provide evidence for the following verbal structure:

(68) $[$ AspP/PredP Asp/Pred [NegP Neg [VoiceP Voice [vP v VP ]]]]

\subsection{The position of the verb's arguments}

\subsubsection{The position of the object}

Gerunds with $-t$ are predominantly verb final and the object is always preverbal. ${ }^{15}$ In order to find out what position the object occupies, we must look at examples with adverbs and negation. As shown by (63), repeated below as (69a), the object precedes the manner adverb. Furthermore, in all examples that feature both an object and negation, the object precedes negation (69b). (67) shows that the object precedes the VM position, too.

(69) a. vetkez-t-em ... [mas ember iozag-a-t gonozol keuan-t-om-ba] sin-PST-1SG other man goods-POSS-ACC viciously wish-t-1SG-INE 'I have sinned in viciously wanting (to have) the goods of others' (Virginia C. 4 r)

b. vadol-om en bwn-wm-eth [hegÿhaz-nak het zentseg-et accuse-1SG I sin-1SG-ACC church-DAT seven sacrament-ACC

nem tiztel-t-em-be]

not revere-t-1sG-INE

'I am accusing myself of the sin of not revering the seven sacraments of the church'

(Virginia C. $6 \mathrm{v}$ )

${ }^{15}$ In the few known non-verb final examples, the postverbal constituent is an oblique PP. Two examples with a constituent following the non-finite verb are shown in (i).

(i) a. tèttèt-nè [è-t-è-t az aldozat-ok-nac huf-i-bol] pretend-COND.3SG eat-t-3SG-ACC the victim-PL-DAT flesh-PL-ELA

'he pretended his eating of the flesh of the victims' (Vienna C. 91)

b. meg-bā-t-ac [èl-fordol-t-ok-at o iftèn-èk-nç zolǵalat't'-a-tol] PRT-regret-PST-3PL away-turn-t-3PL-ACC they god-3PL-DAT service-POSS-DEL 'they regretted turning away from serving their God'

(Vienna C. 19)

We might interpret these data to mean that the verb-final character of - $t$ gerunds is a strong tendency rather than an absolute rule. Alternatively, examples such as 
I suggest that the object moves out of the VP and ends up occupying a position in the IP domain as a result of scrambling. I will remain uncommitted with regard to the label of the landing site and label it FP for functional projection. ${ }^{16}$

(70) [FP object [AspP/PredP Asp/Pred [NegP Neg [VoiceP Voice [vP subject v[VP V ]]]]]

\subsubsection{The position of the subject}

Whenever $-t$ gerunds have an overt subject, it appears on the left edge of the gerund.

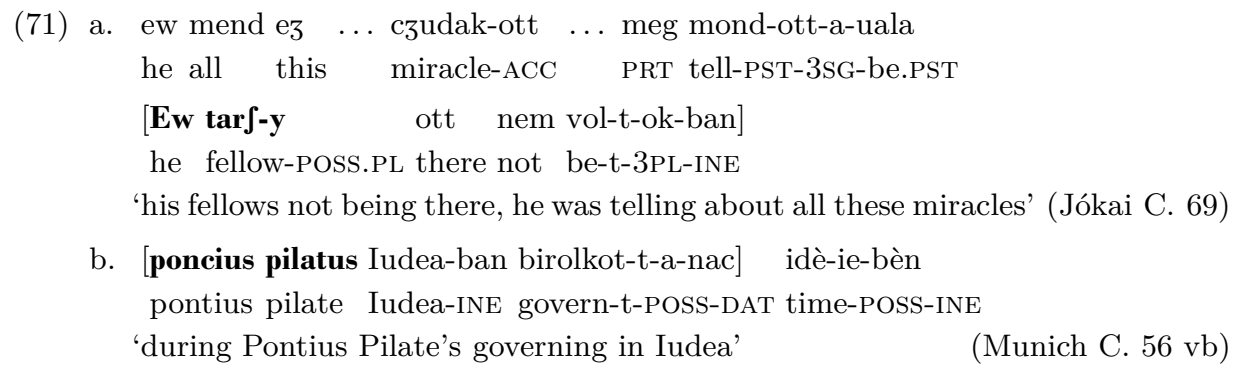

This fact can be interpreted in two ways. If the subject is within the extended verbal projection, then its position above locative adverbs and negation might be taken as evidence that $\mathrm{TP}$ is projected within gerunds. ${ }^{17}$ Tóth (2011b) takes this track: she assumes that - $t$ gerunds contain a TP, and the subject raises to spec TP to satisfy an EPP feature. There is another logical possibility, however: the left peripheral position of the subject might be taken as evidence that the subject raises out of the extended $\mathrm{vP}$ of the gerund and lands in the nominal layers, in the position of regular possessors (or alternatively, it is merged directly in a nominal functional projection, and controls a PRO subject in the clause).

(i) could be analyzed as involving extraposition from (or extraposition to the right periphery of) the extended $\mathrm{vP}$. In this case it would be possible to maintain that - $t$ gerunds belong to the group of strictly head-final non-finites in Old Hungarian.

${ }^{16}$ A reviewer suggests that in (67) and (69) the object might be in a gerund-internal TopP. In the following paragraphs I will argue that Old Hungarian gerunds have a truncated left periphery: TP and the projections above TP are not projected in them. In the approach taken in this paper, it is thus not possible to identify the position of the object as spec TopP.

17 The examples with an overt subject I know of feature an intransitive verb, so there is no direct evidence for the ordering of the subject and the object. Given that 
How can we tell which interpretation of the data is right? The surface position of nominal possessors is on the left periphery of the DP (see Bartos 2000). If the subject of $-t$ gerunds ends up in the nominal layers in the possessor position, then any DP-internal material that is merged between $\mathrm{NP}$ and the possessor's surface position should follow the subject. On the other hand, if the subject stays in spec TP, then any DP-internal material merged between NP and the left periphery of the DP should precede the subject. The DP-internal elements that could serve as relevant signposts here are adjectives, adjectival participles, and numerals. However, all of them are incompatible with Old Hungarian verbal gerunds, so other diagnostics must be found for the height of the subject.

The morphological marking of the subject is an important clue in this regard. Recall that the subject is either morphologically unmarked (which can be taken to be Nominative marked or caseless) or Dative marked. Tóth argues that $-t$ gerunds have a TP with a $[-\mathrm{T}]$ feature specification, and so they cannot assign structural case to their subject. The subject receives either lexical Nominative or Dative case.

This assumption is problematic on several grounds. The first problem is the notion of lexical Nominative case: under the most widespread conception of Nominative, it is a structural case by definition. If Nominative could also have a lexical variety, then we should be able to see it in several environments where structural case cannot be assigned, contrary to fact.

The second problem is that putting gerunds aside, the overt subject of Old Hungarian non-finite clauses always bears one fixed case. When infinitives have a $\phi$-feature independent (i.e., a non-controlled, non-coreferent) subject, the subject may only bear Dative case, ${ }^{18}$ and when adjectival and adverbial participles have a $\phi$-feature independent subject, the subject must be morphologically unmarked.

(72) (ke)kel-uala [ew zerzet-e-nek

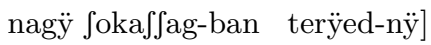

must-PST he holy.order-POSS.3SG-DAT big multitude-INE spead-ACC

'his order had to spread among many people(s)' (Jókai C. 13) infinitive

Proto-Hungarian was SOV and Old Hungarian and modern Hungarian are SVO, I will assume that the subject raises to a position that is higher than the landing site of the object.

18 The Dative marked nominal in this example denotes an inanimate entity. This rules out the possibility that the Dative DP is merged as an experiencer in the matrix clause, and it controls a PRO subject in the infinitive. See Tóth $(2000 ; 2011 \mathrm{a})$ on the distinction between overt infinitival Dative subjects and Dative control. 
(73)

eerdeml-yók az [ew megh yger-tt-e] bodogfag-nak dychófeg-ee-t

deserve-1PL the he PRT promise-PART-3SG happiness-DAT glory-POSS-ACC

'we deserve the glory of the happiness he promised' (Érdy C. 96) adj. participle

(74) $[$ Es azoc e-uèn $]$ ve-ue $\quad \mathrm{i}^{\mathrm{c}} \quad \mathrm{a} \cdot$ kenèr-èt

and those eat-PART take-PST.3SG Jesus the bread-ACC

'and as they did eat, Jesus took bread'

(Munich C. 50vb) adv. participle

If the case of the subject were indeed determined internally to the extended $\mathrm{vP}$ of the gerund, then we would expect that gerunds, like all other nonfinites, settle for one specific subject case. This is patently not the case, however. Furthermore, the subject of the gerund bears exactly those cases that possessors do: they have Dative case or they are morphologically unmarked.

(75) ew haz-a-ban

he house-POSS.3SG-INE

'in his house'

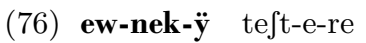

he-dat-3SG body-POSS.3SG-SUB

'onto his body'

(Jókai C. 142)

In Tóth's analysis it is a coincidence that the same two cases are found on the gerundival subject and on ordinary possessors. Ideally, however, the following facts should be linked: (i) of all Old Hungarian non-finites, the extended $\mathrm{vP}$ is embedded under nominal projections only in gerunds, and (ii) of all Old Hungarian non-finites, it is only the subject of gerunds that is case-marked like a possessor.

Based on these considerations, I suggest that it is not the case that the subject of $-t$ gerunds receives inherent case in spec TP. I propose that in order to receive case, the subject must raise to the nominal layers and land in the position of ordinary possessors, where it can be case-licensed in the same way as possessors: as a morphologically unmarked DP or as a Dative marked DP. Unlike in Tóth's analysis, in this approach it is not an accident that the same cases are available to possessors and the subject of - $t$ gerunds: this fact follows because gerundival subjects become derived possessors.

The derived possessor analysis can also be supported with three empirical arguments. Firstly, this proposal gives a natural account of the fact that gerunds are obligatorily possessed: they bear the possessedness marker $-j a /-j e /-a /-e$ and the possessive agreement. These affixes are obligatory on an ordinary noun if and only if there is a possessor in the nominal functional hierarchy of that noun. If the subject of $-t$ gerunds raises out of the extended $v \mathrm{P}$ to the position of possessors, then there is a (derived) pos- 
sessor in the nominal functional hierarchy of the nominalized clause, and with the presence of a possessor, the obligatory presence of the possessedness marker $-j a /-j e /-a /-e$ and the possessive agreement is also correctly predicted. On the other hand, if the subject stays in the downstairs clause and gets inherent case there, as in Tóth's account, then the fact that $-t$ gerunds are formally marked like possessa remains a mystery.

Secondly, the type of possessive agreement that the gerund's subject triggers also provides evidence that this subject is a surface possessor rather than a surface subject. A plural lexical noun as a Nominative subject triggers plural agreement on the verb (77).

(77) a ferfi-ac èuèz-e-nèc

the man-PL row-PST-3PL

'the men were rowing'

(Vienna C. 241)

On the other hand, a plural lexical possessor (whether unmarked or Dative marked) is compatible with two different agreement patterns. Such a possessor may trigger plural agreement on the possessum (78), but no agreement is also possible (in fact, this is the more frequent case). In the latter case the possessum is only marked with the possessedness marker $-j a /-j e /-a /-e(79)$.

(78) toluay ferfi-ak-nak rèitec hèl-ec

robber man-PL-DAT hiding place-3PL

'the hiding place of robbers'

(Vienna C. 189) agreeing lexical possessor

(79) ferfÿ-ak-nak tÿztes gozedelm-e

man-PL-DAT honourable victory-POSS

'the honourable victory of men'

(Peer C. 168 r) no agreement

In order to find out whether the subject of $-t$ gerunds is a surface subject or surface possessor, we must look at what sort of possessive marking is triggered on the nominalized verb by a plural lexical noun. Tóth's analysis predicts that there is always plural agreement on the verb, as in her account the gerund's subject is in the canonical subject position spec TP. The derived possessor analysis, on the other hand, predicts that both plural agreement and no agreement are found, as this is the pattern that we find with possessors. This means that the crucial point is whether there are any gerunds with a plural lexical subject and no agreement, as an example like this would only be compatible with the derived possessor analysis. It turns out that such examples indeed exist. Consider (80), in which the 
plural lexical subject $M \bar{e} d$ a nep-èc 'all the peoples' triggers no agreement; only the possessedness marker $-a$ is present.

(80) [Mēd a nep-èc hall-at-a-ra] ke mōd-a

all the people-PL hear-t-POsS-SUB in.turn say-PST.3SG

'in turn, upon all the people's hearing he said'

(Munich C. 79vb)

Compare the corresponding hypothetical example with plural agreement (with Modern Hungarian orthography): ${ }^{19}$

(81) mind a nép-ek hall-at-uk-ra

all the people-PL hear-t-3PL-SUB

'to all the people's hearing'

This argument can also be repeated for the plural marked pronoun mynden$e k$ 'all'. Mynden-ek in the subject position always triggers plural agreement on the verb (82), however, as a possessor it may trigger plural agreement or no agreement at all (83).

(82) mindenek chodalkoz-na-nak every-PL marvel-COND-3PL

'everybody would marvel'

(Lázár C. 33r)

(83) a. mynden-ek hallaa $\int-\mathbf{a}-$ ra

every-PL hearing-POSS-SUB

'at everbody's hearing'

(Jordánszky C. 241)

b. mýnden-ek kez-ók

every-PL hand-3PL

'everybody's hands' (lit. 'everybody's hand')

(Jordánszky C. VIIb)

${ }^{19}$ For the sake of completeness, I also provide an example with plural agreement on the gerund.

(i) ew mend ez ... czuda-k-ott ... meg mond-ott-a-uala

he all this miracle-PL-ACC PRT tell-PST-3SG-was

[Ew tar $\int-y \quad$ ott nem vol-t-ok-ban]

he fellow-POSS.PL there not be-t-3PL-INE

'his fellows not being there, he was telling about all these miracles'(Jókai C. 69)

Compare the corresponding hypothetical example with no agreement:

(ii) ő társ-i ott nem volt-á-ban

his fellow-POSS.PL there not be-t-POSS-INE

'his fellows not being there'

As pointed out above, plural agreement is compatible with both analyses.

Acta Linguistica Hungarica 61, 2014 
Tóth's analysis predicts that mynden-ek as a gerundival subject always triggers plural agreement, while the derived possessor account advocated here predicts that no agreement with mynden-ek is also available. It is again the prediction of the derived possessor analysis that is confirmed: in (84) there is no agreement, only a possessedness marker.

(84) az ember ... [mynden-ek lat-t-a-ra] el men-ee

the man every-PL see-t-POSS-SUB away go-PST.3SG

'and the man left upon everyone's seeing'

(Jordánszky C. 458)

Compare (84) with the hypothetical example with plural agreement (again with Modern Hungarian orthography): ${ }^{20}$

${ }^{20}$ There is another distributional difference between 3PL genuine subjects and possessors that may potentially shed light on the correct analysis of gerundival subjects. Nominative subjects and unmarked possessors can be clearly distinguished in the case of 3PL pronouns. A 3PL pronominal subject is realized as $o-k$ 'he/she/it-PL' and triggers plural agreement on the verb (i).

(i) o-k nez-nèc idègen iftèn-ek-rè

he/she/it-PL look-3PL foreign god-PL-SUB

'they look at foreign gods'

(Vienna C. 184)

$O k$, however, cannot appear in the possessor position. When 3PL pronominal possessors are called for, then $o k$ is obligatorily replaced by its singular counterpart $o$ 'he/she/it', and the plurality of the possessor is indicated only by the possessive agreement on the possessum (ii). This is widely known as Hungarian possessive anti-agreement (Dikken 1999; Bartos 2000; É. Kiss 2002; Dékány 2011).

(ii) o fold-ok-èt

he/she/it land-3PL-ACC

'their land' (not 'their lands' or 'his land(s)')

(Vienna C. 19)

What we need to do, then, is look at gerunds with an overt 3PL subject pronoun. If at the end of the derivation the gerund's subject is in the spec TP subject position and receives lexical Nominative case, as in Tóth's account, then we predict its form to be $o k$, on a par with genuine 3PL Nominative subjects. On the other hand, if the gerundival subject ends up as a possessor at the end of the derivation, then we predict its form to be $o$, on a par with genuine 3PL possessors.

There are two examples available to me in which a gerund has an overt 3PL pronominal subject. Unexpectedly, however, their subjects have different surface forms: one is $o$, as expected with possessive case-licensing in the extended NP (iii), and the other is $o k$, as expected with Nominative case-licensing in the extended $\mathrm{vP}$ (iv).

(iii) fèlèl-e-n $\mathrm{n}^{\mathrm{c}} \quad[\mathbf{o} \quad$ nē tut-t-ok-at $]$ honnan vol-na

answer-PST-3PL he/she/it not know-t-3PL-ACC where be-COND.3SG

'they answered their not knowing where it would be from' (Munich C. 78vb) 
(85) minden-ek lát-t-uk-ra

every-PL see-t-3PL-SUB

'upon everyone's seeing'
(iv) $[\mathbf{o - k}$
a hèg-rol
le źall-att-oc-ban] parācsol-a
he/she/it-PL the mountain-DEL down come-t-3PL-INE order-PST.3SG 'and during their coming down the mountain, (Jesus) ordered'

(Munich C. 44vb)

Tóth's account has to explain (iii), while the present proposal has to explain (iv). I cannot speculate on how Tóth could treat (iii), but I can point out two strategies that might be pursued in my analysis to tackle (iv).

The first strategy is to assume that (iv) features the $-t$ adverbial participle rather than the $-t$ gerund. Recall from section 2 that the $-t$ adverbial participle can have either a referentially bound subject, or a $\phi$-feature independent overt subject with Nominative case. This means that when these participles have a referentially independent 3PL pronominal subject, it appears in the $o k$ Nominative form.
(v) $[\mathrm{o}-\mathrm{c}$
a3 ut-ban ÿar-att-oc]
mōd-a
egnemel o-nek-ÿ

he/she/it-PL the road-INE walk-ADV.PART-3PL say-PST.3SG someone he-DAT-3SG

'while they were walking on the road, somebody said to him' (Munich C. $66 \mathrm{vb}$ )

Some support for this view comes from the fact that (iv) features double - $t$, and the adverbial participle is characteristically written with double $-t$, while the gerund is characteristically written with a single $-t$. Orthography, however, is not standardised and is unreliable in Old Hungarian, so the $-t$ vs. $-t t$ opposition is not decisive.

The weakness of this approach, however, is that participles are normally not marked for case. In Modern Hungarian in some exceptional cases the present participle can bear precisely the Inessive case featured in (iv): compare the regular adjectival use in (vi) and (viii) with the exceptional use with Inessive marking in (vii) and (ix).
(vi) a le-men-ő
Nap (vii) a Nap le-men-ő-ben
volt
the down-go-PRS.PART Sun
the Sun down-go-PRS.PART-INE was
'the descending Sun'
'the Sun was descending'
lit. 'the Sun was in (a) downgoing (state)'
(viii) a kifogyó
cukor
the out-run-PRS.PART sugar
(ix) a cukor ki-fogy-ó-ban van
the sugar out-run-PRS.PART be.3SG
'the sugar that is running out'
'the sugar is running out' lit. 'the sugar is in (a) running out (state)'

However, I do not know whether examples like (vii) can be found in Old Hungarian or not, and I am also not aware of any genuine $-t$ adverbial participles that bear case.

The other strategy, which is perhaps more plausible, is to say that in (iv) the scriptor mixed up two categories: he started this constituent as a $-t$ adverbial participle, so the example has an oc subject characteristic of adverbial participles, but as a result of performance error he switched to a $-t$ gerund in the middle of the non-finite, and so finished it with a $-t+$ agreement + case sequence characteristic of gerunds. 
Thirdly, whether a pronominal gerundival subject may or may not cooccur with the definite article also sheds light on the syntactic position of the subject. Personal pronouns in the canonical subject position spec TP cannot be preceded by the definitie article (86).

(86) tẃ zol-tok vala

you speak-2PL be.PST

'you were speaking'

(Könyvecse 19 r)

Personal pronoun possessors, on the other hand, may be preceded by the definite article, though this is not necessary in Old Hungarian (see Egedi 2014a; b on the gradual extension of the definite article to more and more environments in this period).

(87) a. az tẃ neu-etek

the you name-2PL

'your name'

(Könyvecse 2 r)

b. legÿ-en tẃ zolga-tok

be-IMP.3SG you servant-2PL

'let (him) be your servant'

(Könyvecse 19 v)

Tóth's analysis and the present proposal make different predictions again. Under Tóth's spec TP analysis we expect that a gerund's personal pronoun subject is never preceded by the definite article, while under my derived possessor account we do expect to find such examples. Definite article + personal pronoun sequences can indeed be found in gerunds, and this supports the derived possessor analysis.

(88) gÿakorta kel meg keerdez-n-wnk az o tÿzta wol-t-at

often must PRT ask-INF-1PL the it clear be-t-POSS-ACC

'we must often ask if it (i.e., our conscience) is clear'

(lit. 'we must often ask its clear being')

(Érsekújvári C. 271 va)

(89) az o nagy wolta

the he great be-t-Poss

'his greatness' (lit. 'his being great')

(Érsekújvári C. 271 va)

We can thus conclude that the gerund's subject is not in spec TP in the extended vP. Instead, it is in the position of possessors (spec AgrP for unmarked possessors and spec DP for Dative possessors). 


\subsection{Consequences for the size of the extended vP}

If the gerund's subject is not sitting in spec TP, as I suggested, then there is no direct evidence that $\mathrm{TP}$ is projected at all. It might be the case that TP is projected but cannot assign case to the subject, so the subject touches down in spec TP but cannot stay there without violating the Case Filter. On the other hand, it is also possible that the subject needs to move to the nominal layers because the downstairs TP is never projected. The problem of choosing between these two analyses proves not to be easy to solve. Panagiotidis and Grohmann (2009) and Moulton (2004) argue on theoretical grounds that nominalizations may only target specific categories: vP and TP (and for Panagiotidis and Grohmann 2009 also CP) are targets, but intermediate categories such as AspP are not. On the other hand, Alexiadou (2005) argues that high sentence adverbials are generally not available in gerunds, and this supports the view that gerunds do not project all the way up to TP. Given the scarcity of non-locative adverbials in Old Hungarian - $t$ gerunds and the fact that the structure cannot be tested with native speakers, direct empirical evidence for or against the existence of TP in these non-finites remains elusive.

The existence of the TP layer could be proven indirectly if we could show that some functional projection higher than TP is present in - $t$ gerunds. There is indeed some evidence that could be taken as an indication of a (perhaps defective) lower CP domain. Consider the "discontinuous gerund" examples in (90): here the matrix verb is flanked by the gerundival verb and some other material that clearly forms a constituent with the gerundival verb at the beginning of the derivation. ${ }^{21}$

(90) a. ha [az ístení íozag-nac esmet-í-re $]_{i}$ kevan-od

if the divine goods-DAT knowledge-POSS.PL-SUB wish-2SG

[ $t_{i}$ íut-t-od-at] go-t-2SG-ACC

'if you wish your gaining knowledge of divine things'

(Nagyszombat C. 3)

b. bè men-uen a haz-ba [Jenki-nèc $\left.\int e m\right]_{i}$ akar-ia vala

in go-PART the house-ILL nobody-DAT not want-3SG be.PST

[ $t_{i}$ meg-tut-t-a-t]

PRT-know-t-POSS-ACC

'and going into the house, he didn't want anybody knowing (about it)'

(Munich C. $43 \mathrm{ra}$ )

${ }^{21}$ Such discontinuous constructions are attested with many types of Old Hungarian non-finites. Their acceptability in Modern Hungarian is often degraded. 
One way to account for the discontinuous gerunds in (90) is that some escape hatch in the $\mathrm{CP}$-domain is available in gerunds to a limited extent. ${ }^{22}$ If this were the case, then it would provide an argument that TP, too, must be present in $-t$ gerunds. This conclusion does not follow, however. As Pires (2001) argues, gerunds that are bigger than vPs but do not project beyond TP are not phases, and so extraction from them proceeds in a onefell-swoop fashion without touching down in an edge position. Conclusive evidence for $\mathrm{TP}$ in $-t$ gerunds thus remains to be found.

Let us summarize the results of the preceding discussion. I have argued that based on the range of available functional elements and the object's position, there is direct evidence for the following clausal functional hierarchy in - $t$ gerunds:

(91) [FP object [AspP/PredP Asp/Pred [NegP Neg [VoiceP Voice [vP v [VP V ]]]]]

The subject is not in the extended vP but in the nominal functional projection hosting possessors. I have further argued that there is no direct evidence for a TP, but its presence cannot be excluded beyond peradventure either. Below I will represent gerunds without a TP layer.

\subsection{Nominalizing the extended vP}

Having explored the verbal functional projections of $-t$ gerunds, let us now turn to the available nominal projections. Alexiadou (2005); Alexiadou et al. (2010b) and Alexiadou et al. (2011) argue that nominalizations may arise in two ways: with and without a designated nominalizer. The presence of a nominalizer proper licenses nominal functional projections that harbour NP-modifiers such as ClassifierP, AP, NumP, and so the presence of the nominalizer correlates with the presence of nominal internal properties (e.g., modification by determiners and adjectives). A case in point is the English nominal gerund: its -ing suffix spells out a $n$ nominalizing head, and adjectives, determiners, etc. are licensed in the structure.

(92) [DP [NumP [ClassP [nP n(-ing) [VP ]]]]]

(Alexiadou et al. 2010b)

Not all nominalizations contain a nominalizer, however. The extended vP may be embedded directly by a nominal functional head, for instance D. As these structures have no nominalizer, the functional projections that

${ }^{22}$ Limited extraction from gerunds is also available in Modern Greek. See Panagiotidis (2010) and references cited therein. 
harbour NP-modifiers such as $\mathrm{Cl}$ (assifier)P, AP, NumP are not licensed, and so these nominalizations lack nominal internal properties. A case in point is the English verbal gerund. The -ing ending here spells out an Aspect head, and AspP is the complement of $\mathrm{D}$ without the mediation of a nominalizer. ${ }^{23}$

(93) [DP D [AspP Asp(-ing) [VP ]]

(Alexiadou et al. 2010b)

In Tóth's analysis gerunds contain a nominalizer: the extended $\mathrm{vP}$ is the complement of a nominalizing head Nom, and $-t$ is the spellout of this head. The Old Hungarian verbal gerund is a nominalization that lacks nominal internal properties, however: NP-modifiers such as adjectives, classifiers, numerals, and determiners are not licensed in the structure. Following the analysis of Alexiadou (2005); Alexiadou et al. (2010b) and Alexiadou et al. (2011), I suggest that - $t$ gerunds do not have a nominalizer; the extended vP is merged directly as a sister to the Poss head.

(94) [PossP Poss [FP object $[$ AspP/PredP Asp/Pred(-t) $[$ NegP Neg

[VoiceP Voice [vP v [vP V ] ]]]]]

If Old Hungarian verbal gerunds do not have a nominalizer, and the extended $\mathrm{vP}$ is the complement of PossP, then - $t$ must realize a functional head in the verbal portion of the gerund. There are two plausible positions for $-t$ in (94): the $\mathrm{F}$ head and the AspP/PredP head. I will take $-t$ to realize the Asp/Pred head, noting that it is not possible to test the aspectual properties of Old Hungarian verbal gerunds with for-PPs or in-PPs, and so we cannot tell definitely what sort of aspectual information is encoded in $-t$.

Apart from the possessedness marker hosted in PossP, gerunds also take regular possessive agreement markers and nominal casemarking. As we have seen in section (4.1), possessive agreement is hosted in AgrP, while case-markers are in KP topping off the nominal phrase. As the subject is a derived possessor, and Dative possessors are in spec DP, DP must also be projected in - $t$ gerunds. We thus have evidence for the functional hierarchy in (95).

23 The reason why Alexiadou (2005); Alexiadou et al. (2010b) and Alexiadou et al. (2011) take the -ing of verbal gerunds to contribute aspectual information is that a telic event in the verbal gerund admits for-PP modification, and so these gerunds must have an imperfective outer aspect head on top of vP (see also Borer 2005).

(i) John wrote the letter in 3 days $/{ }^{*}$ for 3 days. (Alexiadou et al. 2010b, ex. 36a)

(ii) John's writing the letter for 3 days annoyed everybody. (ibid., ex. 36b) 
(95) $[\mathrm{KP}$ K $[\mathrm{DP} D[$ AgrP Agr [PossP Poss [FP object [AspP/PredP Asp/Pred(-t)

[NegP Neg [VoiceP Voice [vP v [vP V ] ]]]]]]]]]

Gerunds with - $t$ cannot be pluralized, nor do they take nominal modifiers such as adjectives, relative clauses, or demonstratives. I take this as evidence that apart from KP, DP, AgrP, and PossP, no other nominal functional projections are licensed in the structure.

\subsection{Summary of the analysis: the structure of $-t$ gerunds}

Let us take stock of the proposed functional structure in Old Hungarian - $t$ gerunds. I suggested that the structure is as in (96).

(96) [KP K [DP D [AgrP Agr [PossP Poss [FP object [AspP/PredP Asp/Pred [NegP Neg [VoiceP Voice [vP subject v [vP V ] ] ]]]]]]]]

The representation of a gerund with an overt Dative marked subject such as (97) is given in (98), on the facing page. The embedded verbal projection is no bigger than AspP/PredP. ${ }^{24}$ The subject moves out of AspP/PredP into the surface position of Dative marked possessors, spec DP, and it gets Dative case in that position.

(97) waar-ÿa wala $\ldots$ [az eë̈-nek setetwl-t-e-t]

wait-3SG be.PST the night-DAT darken-t-POSS-ACC

'she was waiting the falling (lit. darkening) of the night' (Érsekújvári C. 232 ra)

The structure of a gerund with an overt, morphologically unmarked subject such as (99) is shown in (100). The subject moves out of AspP into the surface position of unmarked possessors, spec AgrP, and it is case-licensed in that position. ${ }^{25}$

${ }^{24}$ I follow den Dikken $(2010,74)$ and assume that "functional structure is selectively present" (original emphasis). Since (99) has no object, I assume that the landing site of the oject, FP, is not projected above AspP/PredP.

${ }^{25}$ Unmarked possessors might be taken to bear Nominative case or be caseless. In the first scenario, the gerund's subject gets Nominative case in spec AgrP, and so it naturally avoids violating the Case Filter. Several researchers argue, however, that unmarked possessors are caseless, in fact (Bartos 1999; É. Kiss 2002; Dékány 2011). In this analysis the question arises as to why the subject would move to the nominal layers if it does not get case there either, and how it could survive without violating the Case Filter. In Dékány (to appear) I argue that the reason why possessors may stay caseless is that they are predicates (den Dikken 2006; 
(98)

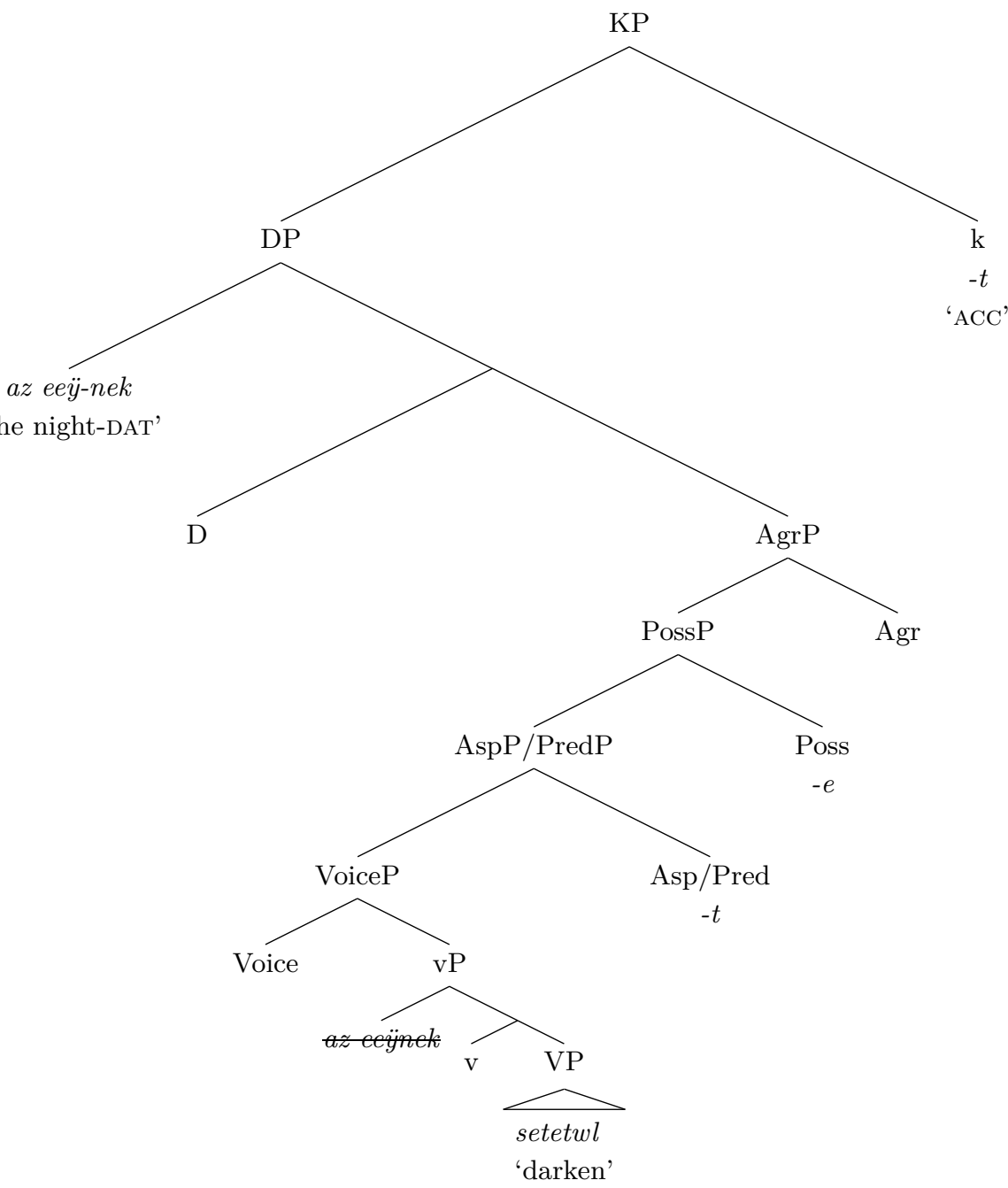

(99) eressen [weer fol-t-a-ÿgh] ostoroz-tat-al

severely blood flow-t-POSS-TER whip-PASS-PST.2SG

'you were being severely whipped until you were bleeding'

(lit. 'until blood's flowing')

(Thewrewk C. 96 v)

2007), and predicate noun phrases are typically caseless (though there are some exceptions). In this approach the reason why the gerund's subject moves out of AspP/PredP to spec AgrP is that as a derived possessor it can remain caseless. 
$(100)$



As for gerunds with a covert subject that is not coreferent with any of the matrix arguments, e.g., (101), I assume that they have the same structure as (98) and (100), except that their derived possessor undergoes regular pro-drop. ${ }^{26}$

26 Pro-drop of possessors is common in Old Hungarian (as well as contemporary Hungarian). Compare the following examples:

(i) unmarked possessor:

te nev-ed-ben

(ii) dative possessor:

you name-2SG-INESS

te-nek-ed New-ed

'in your name'

you-DAT-2SG name-2SG

(Lavs Sancti Nicolai Pontificis 2/7)

'your name'

(Székelyudvarhely C. 29 v)

Acta Linguistica Hungarica 61, 2014 
(101) meg' nýt-odt-ad [bel mene-t-y-tt' te lakodalm-ad-ba]

PRT open-PST-2SG in go-t-POSS.3SG-ACC you nuptials-POSS.2SG-ILL

'you have opened (the possibility of) his going to your nuptials' (Festetics C. 387)

(102)
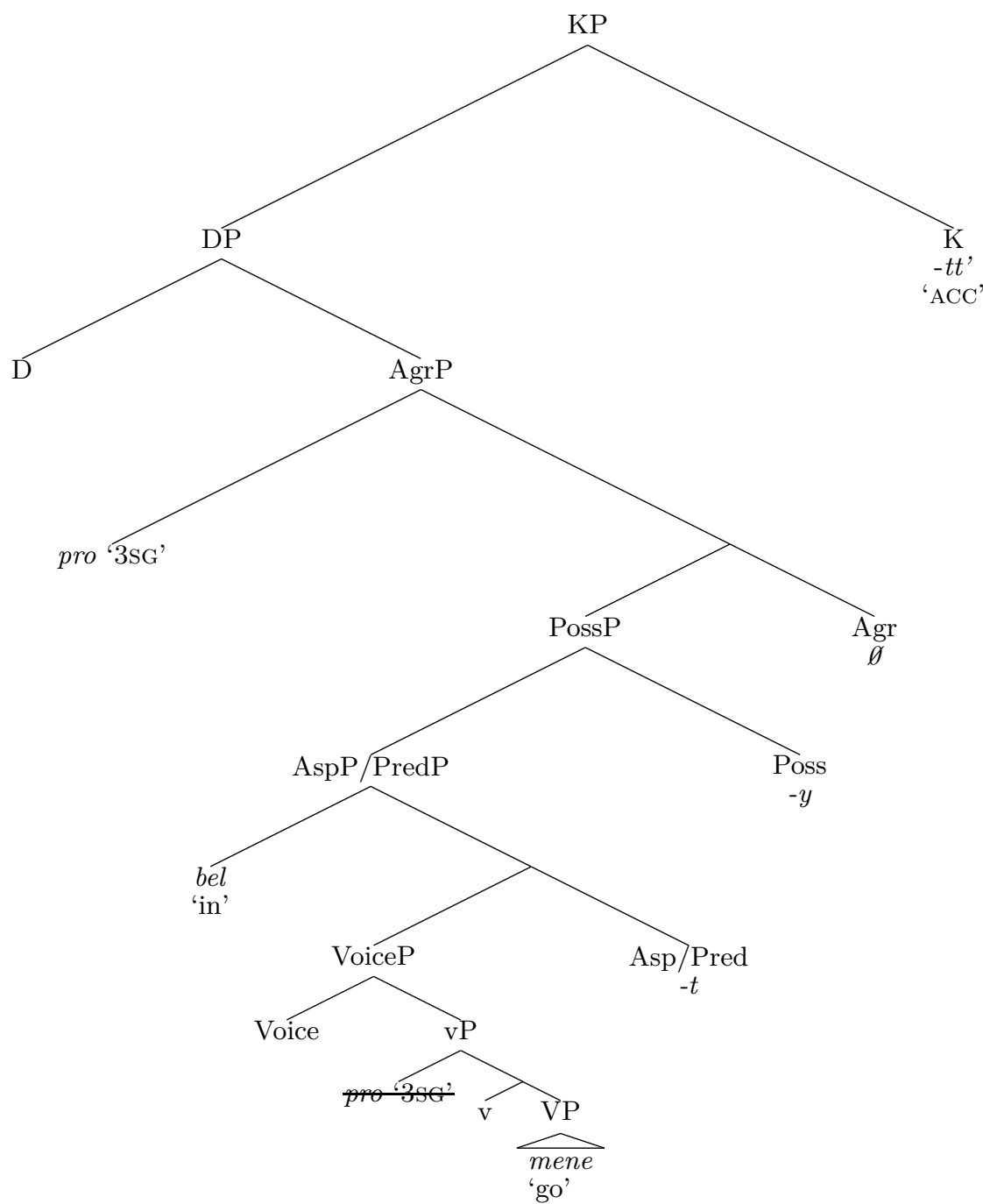

(iii) pro-drop:

$\mathrm{Az} \quad \mathrm{ki}-\mathrm{k}$

tanóság-ra

nev-ed-ben

ad-at-nak

that who-PL testimony-SUBLAT name-2SG-INESS give-PASS-3PL

'those who are sent to give testimony in your name'

(Lavs Sancti Nicolai Pontificis 2/5)

Acta Linguistica Hungarica 61, 2014 
Finally, I also propose a pro-drop analysis for gerunds with a covert subject that is coreferent with a matrix argument, e.g., (103), the corresponding tree is shown in (104) on the facing page.

(103) ÿmad-lak teged-eth [menÿorzagh-ba fel men-t-ed-erth]

worship-1SG you-ACC heaven-ILL up go-t-2SG-CAU

'I worship you for your ascending to heaven'

(Pozsony C. $13 \mathrm{v}-14 \mathrm{r}$ )

As already mentioned before, Tóth assumes a controlled pro subject in these examples. A referentially independent pro plus pro drop is independently necessary for examples like (101). As this analysis can also capture examples like (103), it is more economical, and therefore desirable, to extend this analysis to these kinds of gerunds, too. The only difference bewteen (102) and (104) is that in the latter the pro subject happens to refer to the same individual as one of the matrix arguments.

\section{Conclusions}

In this paper I sought to answer the following questions regarding the structure of Old Hungarian - $t$ gerunds: (i) how much verbal structure they have, (ii) how much nominal structure they have, and (iii) what is the syntactic status of the overt, non-coreferent subject. As far as the amount of verbal structure is concerned, I suggested that $-t$ gerunds project at least up to an IP-internal functional projection above AspP/PredP, and the object of the gerundival verb is displaced into the specifier of this functional projection. I have not found direct evidence for the existence of $\mathrm{TP}$ in $-t$ gerunds.

As for the subject of $-t$ gerunds, I proposed that the subject does not receive case in the extended $\mathrm{vP}$ (because there is no $\mathrm{TP}$ that could assign case to it), so it raises into the nominal functional layers, where it is caselicensed as a possessor. The presence of possessive agreement was one of the crucial pieces of evidence in this regard: possessive agreement is present on ordinary nouns if and only if there is a possessor in the structure, and if the subject could get case internally to the extended $\mathrm{vP}$ without moving to the possessor position, then we could not explain why this particular type of nominalization has to be formally possessed.

As for the available nominal structure, I suggested that there is evidence for three DP-internal functional projections: PossP (hosting the possessedness marker), AgrP (hosting the possessive agreement and the unmarked possessor), and DP (hosting Dative possessors on the surface). 
$(104)$

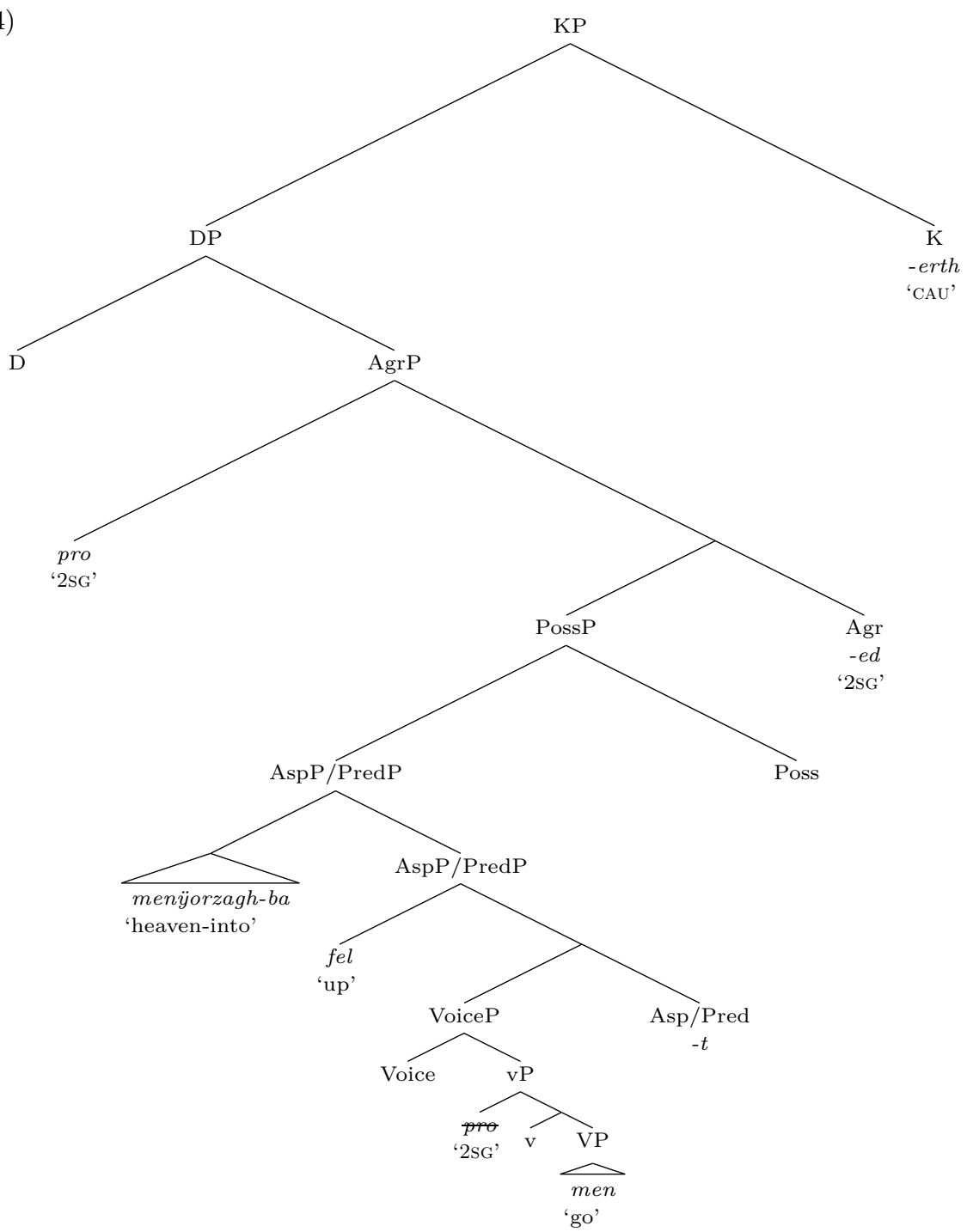

Alexiadou (2005); Alexiadou et al. (2010a; 2011) argue that English verbal gerunds (aka Poss-ing gerunds, e.g., John's reading the book) have very little nominal structure: only a DP projection is present, hosting the possessive marked subject. It is well known that the same type of nominalization (e.g., verbal gerund, nominal gerund, nominal infinitive, etc.) may have more nominal functional projections in some languages than in others (see Alexiadou et al. 2011 for examples). Therefore it is perfectly possible that there is variation between English and Old Hungarian in this 
regard: English verbal gerunds have only DP, while Old Hungarian verbal gerunds have PossP, AgrP, and DP.

However, there is another logical possiblity, too. We have seen that the simplified structure of possessive expressions in Hungarian is (105).

(105) [DP D [AgrP Agr(eement) [NumP Num [PossP Poss(-ja/-je/-a/-e) NP ]]]]

Bartos $(1999 ; 2000)$ argues that the possessor is merged into the structure in spec PossP. If this is on the right track, then PossP must be present in English possessive constructions as well. The only difference between English and Old Hungarian in this respect is the phonological exponent of the Poss head ( $\varnothing$ versus $-j a /-j e /-a /-e$ ). Furthermore, if the hierarchy of functional projections is universal (Cinque 1999), then English, too must have the possessor-related functional projection AgrP below DP. Alexiadou et al. (2007, part IV, chapter 2) argue that this is indeed the case: possessors that move to spec DP or higher, such as English possessors, have an intermediate landing site in spec AgrP. The difference between English and Old Hungarian in this regard is the $\varnothing$ versus overt exponence of the Agr head, and that possessor movement from spec AgrP to spec DP takes place with all English possessors but in Hungarian it occurs only with Dative possessors.

The upshot of all this is that (105) is the structure of English possessives, too. This raises the possibility that English Poss-ing gerunds, too, have not only DP, but all possessive-related functional heads: PossP, AgrP, and DP. As the Poss and Agr heads are always silent in English, however, it is impossible to tell on an empirical basis whether PossP and AgrP are present or absent in English Poss-ing gerunds. Whether Universal Grammar allows for the possibility of projecting only DP in verbal gerunds with a possessive marked subject, or all possessive-related functional projections must be present when the gerund's subject is a surface possessor is an issue that only a wider cross-linguistic study may adjudicate. Languages that will be enlightening in this regard (i) have verbal gerunds in which the subject is morphologically marked as a possessor and (ii) have an overt spellout for either the Poss head or the Agr head, or possibly both. If some of these languages are such that their possessed nouns obligatorily bear the Poss or Agr suffix but their verbal gerunds do not (or not obligatorily do so), then these languages show indisputable evidence that in verbal gerunds with a possessive marked subject it is possible to project only the DP. On the other hand, if all these languages are such that their verbal gerunds must bear the Poss or Agr suffix just like ordinary possessed nouns, then this leads to the conclusion that all possessive-related functional heads must 
be projected in verbal gerunds with a possessive-marked subject. A crosslinguistic study comparing the morphology of possessed nouns and verbal gerunds with a possessive marked subject within individual languages would yield rich rewards, but this remains for future research.

\section{Primary sources}

Apor C: Late 15th-early 16th c. György Volf (ed.) Apor-kódex. Budapest, 1879.

Birk C: 1474. István Pusztai (ed.) Birk-kódex. Szent Ágoston regulái és a domonkosrendi apácák konstitúciói. Facsimile, transcription of the original record, Latin equivalent, and introduction. Budapest: Akadémiai Kiadó, 1960.

Döbrentei C: 1508. Csilla Abaffy, Csilla T. Szabó and Edit Madas (eds.) Döbrenteikódex. Halábori Bertalan keze írásával. Facsimile, transcription of the original record, with introduction and notes. Budapest: Argumentum Kiadó \& Magyar Nyelvtudományi Társaság, 1995.

Érdy C: 1524-1527. Unpublished transcription of the original text, received from the Sermones project (http://sermones.elte.hu/erdy/)

Érsekújvári C: 1529-1531. Lea Haader (ed.) Érsekújvári kódex. Budapest: Tinta Könyvkiadó, 2013.

Festetics C: before 1494. Csilla Abaffy (ed.) Festetics-kódex. Facsimile, transcription of the original record, with introduction and notes. Budapest: Argumentum, Magyar Nyelvtudományi Társaság, 1996.

Guary C: before 1495. Dénes Szabó (ed.) Guary-kódex. Codices Hungarici 3. Budapest, 1944.

Jókai C: c. 1440. János P. Balázs (ed.) Jókai-kódex. Transcription of the original record and its latin equivalent with introduction and notes. Budapest: Akadémiai Kiadó, 1981.

Jordánszky C: 1516-1519. A Jordánszky-kódex bibliafordítása. Printed by Ferenc Toldy. Introduction by György Volf. 1888.

Könyvecse: 1521. István Pusztai (ed.) Könyvecse az szent apostoloknak méltóságokról. Facsimile, transcription of the original record, with introduction and notes. Budapest: Magyar Nyelvtudományi Társaság, 1985.

Lázár C: First quarter of the 16th c. Csilla N. Abaffy (ed.) Lázár [Zelma]-kódex. Facsimile, transcription of the original record with notes and introduction. Budapest: Magyar Nyelvtudományi Társaság, 1992.

Level: Attila Hegedűs and Lajos Papp (eds.) Középkori leveleink 1541-ig. Budapest: Tankönyvkiadó, 1991.

Munich C: 1466. Antal Nyíri (ed.) A Müncheni kódex 1466-ból. Transcription of the original record and its latin equivalent. Budapest: Akadémiai Kiadó, 1971.

Nagyszombat C: 1512-1513. Csilla T. Szabó (ed.) Nagyszombati kódex. Facsimile, transcription of the original record, with introduction and notes. Budapest: Argumentum Kiadó \& Magyar Nyelvtudományi Társaság, 2000.

Peer C: Around 1518. Andrea Kacskovics-Reményi and Beatrix Oszkó (eds.) Peer-kódex. Facsimile, transcription of the original record, with introduction and notes. $\mathrm{Bu}-$ dapest: Argumentum Kiadó \& Magyar Nyelvtudományi Társaság, 2000. 
Pozsony C: 1520. Csilla Abaffy, Erzsébet Abaffy and Edit Madas (eds.) Pozsonyi kódex. Facsimile, transcription of the original record, with introduction and notes. Budapest: Magyar Nyelvtudományi Társaság, 2004.

Székelyudvarhely C: 1526-1528. Csilla N. Abaffy (ed.) Székelyudvarhelyi kódex. Facsimile and transcription of the original record with notes. Budapest: Magyar Nyelvtudományi Társaság, 1993.

Thewrewk C: 1531. Judit Balázs and Gabriella Uhl (eds.) Thewrewk-kódex (Régi magyar kódexek 18). Facsimile and transcription of the original record with an introduction and notes. Budapest: MTA Nyelvtudományi Intézet, 1995.

Vienna C: Mid-15th c. Gedeon Mészöly (ed.) Bécsi kódex. Budapest: MTA, 1916.

Virginia C: Early 16th c. Zsuzsa Kovács (ed.) Virginia-kódex. Facsimile, transcription of the original record, with introduction and notes. Budapest: Magyar Nyelvtudományi Társaság, ELTE, 1990.

\section{References}

Abney, Steven Paul. 1987. English NP in its sentential aspect. Doctoral dissertation. MIT.

Alberti, Gábor. 2004. Climbing for aspect: With no rucksack. In É. Kiss \& van Riemsdijk (2004, 253-289).

Alexiadou, Artemis. 2001. Functional structure in nominals: Nominalization and ergativity. Amsterdam \& Philadelphia: John Benjamins.

Alexiadou, Artemis. 2005. Gerund types, the present participle and patterns of derivation. In C. Maienborn and A. Wöllstein-Leisten (eds.) Event arguments in syntax, semantics and discourse. Tübingen: Niemeyer. 139-152.

Alexiadou, Artemis. 2013. Nominal vs. verbal -ing constructions and the development of the English progressive. English Linguistics Research 2. 126-140.

Alexiadou, Artemis, Liliane Haegeman and Melita Stavrou. 2007. Noun phrase in the generative perspective. Berlin \& New York: Mouton de Gruyter.

Alexiadou, Artemis, Gianina Iordăchioaia and Florian Schäfer. 2011. Scaling the variation in Romance and Germanic nominalizations. In H. Perridon and P. Sleeman (eds.) Variation and change in the Romance and Germanic noun phrase: Structure, variation, and change. Amsterdam \& Philadelphia: John Benjamins. 25-40.

Alexiadou, Artemis, Gianina Iordăchioaia and Elena Soare. 2010a. Number/aspect interactions in the syntax of nominalizations: A Distributed Morphology approach. Journal of Linguistics 46. 537-573.

Alexiadou, Artemis, Gianina Iordăchioaia and Elena Soare. 2010b. Plural marking in argument supporting nominalizations. In P. Cabredo-Hofherr and B. Laca (eds.) Layers of aspect. Stanford, CA: CSLI Publications. 1-22.

Bácskai-Atkári, Júlia and Éva Dékány. 2014. From non-finite to finite subordination. The history of embedded clauses. In É. Kiss (2014b, 148-223).

Baker, Mark C. 2005. On gerunds and the theory of categories. Ms., Rutgers University.

Bartos, Huba. 1999. Morfoszintaxis és interpretáció: a magyar inflexiós jelenségek szintaktikai háttere [Morphosyntax and interpretation: The syntactic background of 
Hungarian inflectional phenomena]. Doctoral dissertation. Eötvös Loránd University (ELTE), Budapest.

Bartos, Huba. 2000. Az inflexiós jelenségek szintaktikai háttere [Syntactic background of inflectional phenomena]. In Kiefer (2000, 653-762).

Borer, Hagit. 2005. Structuring sense II: The normal course of events. Oxford: Oxford University Press.

Borsley, Robert D. and Jaklin Kornfilt. 2000. Mixed extended projections. In R. D. Borsley (ed.) The nature and function of syntactic categories. New York: Academic Press. 101-131.

Bresnan, Joan. 1997. Mixed categories as head sharing constructions. In M. Butt and T. H. King (eds.) Proceedings of LFG97. Stanford, CA: CSLI Publications. 1-17.

Broekhuis, Hans and Veronika Hegedüs. 2009. Predicate movement. Lingua 119. 531563.

Cinque, Guglielmo. 1999. Adverbs and functional heads: A cross-linguistic perspective. Oxford: Oxford University Press.

Csirmaz, Anikó. 2004. Particles and phonologically defective predicates. In É. Kiss \& van Riemsdijk (2004, 225-252).

Csirmaz, Anikó. 2006. Particles and a two component theory of aspect. In É. Kiss (2006a, 107-128).

Dékány, Éva. 2011. A profile of the Hungarian DP. The interaction of lexicalization, agreement and linearization with the functional sequence. Doctoral dissertation. University of Troms $\varnothing$, Troms $\varnothing$.

Dékány, Éva. 2014. A nem véges allárendelés (az igenevek) története [The history of non-finite clauses]. In É. Kiss (2014d, 177-238).

Dékány, Éva. to appear. The syntax of anaphoric possessives in Hungarian. Natural Language and Linguistic Theory.

Dikken, Marcel den. 1999. On the structural representation of possession and agreement: The case of (anti-)agreement in Hungarian possessed nominal phrases. In I. Kenesei (ed.) Crossing boundaries: Advances in the theory of Central and Eastern European languages. Amsterdam \& Philadelphia: John Benjamins. 137-178.

Dikken, Marcel den. 2006. Relators and linkers: The syntax of predication, predicate inversion, and the copula. Cambridge, MA: MIT Press.

Dikken, Marcel den. 2007. Amharic relatives and possessives: Definiteness, agreement and the linker. Linguistic Inquiry 38. 302-320.

Dikken, Marcel den. 2010. On the functional structure of locative and directional PPs. In G. Cinque and L. Rizzi (eds.) Mapping spatial PPs and the cartography of syntactic structure. New York: Oxford University Press. 74-126.

É. Kiss, Katalin. 2002. The syntax of Hungarian. Cambridge: Cambridge University Press.

É. Kiss, Katalin (ed.). 2006a. Event structure and the left periphery. Studies on Hungarian. Dordrecht: Springer.

É. Kiss, Katalin. 2006b. The function and the syntax of the verbal particle. In É. Kiss (2006a, 16-55).

É. Kiss, Katalin. 2011. On a type of counterfactual construction. In T. Laczkó and C. O. Ringen (eds.) Approaches to Hungarian 12: Papers from the 2009 Debrecen conference. Amsterdam \& Philadelphia: John Benjamins. 85-107. 
É. Kiss, Katalin. 2013. From Proto-Hungarian SOV to Old Hungarian Top Foc V X*. Diachronica 30. 202-231.

É. Kiss, Katalin. 2014a. Az ómagyar igeidő-rendszer [The Old Hungarian system of tenses]. In É. Kiss (2014d, 60-72).

É. Kiss, Katalin (ed.). 2014b. The evolution of functional left peripheries in Hungarian syntax. Oxford: Oxford University Press.

É. Kiss, Katalin. 2014c. The evolution of functional left peripheries in the Hungarian sentence. In É. Kiss (2014b, 9-55).

É. Kiss, Katalin (ed.). 2014d. Magyar generatív törteneti mondattan [Hungarian generative historical grammar]. Budapest: Akadémiai Kiadó.

É. Kiss, Katalin and Henk van Riemsdijk (eds.). 2004. Verb clusters. A study of Hungarian, German and Dutch. Amsterdam \& Philadelphia: John Benjamins.

Egedi, Barbara. 2013. Plural agreement within possessive constructions in three varieties in Hungarian. Poster presented at the 11th International Conference on the Structure of Hungarian (ICSH11), Piliscsaba.

Egedi, Barbara. 2014a. The DP-cycle in Hungarian and the functional extension of the noun phrase. In É. Kiss (2014b, 56-82).

Egedi, Barbara. 2014b. Fejezetek a főnévi kifejezések strukturális történetéből: Határozottság, névelőhasználat, birtokos szerkezetek [Chapters from the structural history of noun phrases: Definiteness, the definite article, possessive structures]. In É. Kiss (2014d, 95-126).

Hegedüs, Veronika. 2013. Non-verbal predicates and predicate movement in Hungarian. Doctoral dissertation. University of Tilburg.

Hegedüs, Veronika. submitted. Particle-verb order in Old Hungarian and complex predicates. Proceedings of Diachronic Generative Syntax.

Károly, Sándor. 1956. Igenévrendszerünk a kódexirodalom első szakaszában [The nonfinite verb system of Hungarian in the first period of the codex-literature]. Budapest: Akadémiai Kiadó.

Kiefer, Ferenc (ed.). 2000. Strukturális magyar nyelvtan 3. Morfológia [A structural grammar of Hungarian 3. Morphology]. Budapest: Akadémiai Kiadó.

Kim, Yong-Beom. 2001. Distributional properties and endocentricity of English gerunds. In B. Tsou and O. Kwong (eds.) Language, information and computation: proceedings of the 15th Pacific Asia Conference. Hong Kong: City University of Hong Kong. $325-332$.

Laczkó, Tibor. 1995. The syntax of Hungarian noun phrases: A lexical-functional approach. Frankfurt am Main: Peter Lang.

Laczkó, Tibor. 2007. Revisiting possessors in Hungarian DPs: A new perspective. In M. Butt and T. H. King (eds.) Proceedings of LFG07. Stanford, CA: CSLI Publications. 343-362.

Mel'čuk, Igor. 1973. On the possessive forms of the Hungarian noun. In F. Kiefer and N. Ruwet (eds.) Generative grammar in Europe. Dodrecht: Kluwer. 315-332.

Moulton, Keir. 2004. External arguments and gerunds. Toronto Working papers in Linguistics 22. 121-136.

Panagiotidis, Phoevos. 2010. Nonargumental mixed projections. Syntax 13. 165-182. 
Panagiotidis, Phoevos and Kleanthes K. Grohmann. 2009. Mixed projections: Categorial switches and prolific domains. Linguistic Analysis 35. 141-161.

Pires, Acrisio. 2001. Clausal and TP-defective gerunds: Control without Tense. In K. M. and U. Strauss (eds.) Proceedings of NELS 31. Amherst: GLSA Publications. $386-406$

Pires, Acrisio. 2006. The Miminalist syntax of defective domains: Gerunds and infinitives. Linguistik Aktuell/Linguistics Today 98, Amsterdam \& Philadelphia: John Benjamins.

Radics, Katalin. 1992. Fossilized gerunds with possessive endings in Hungarian. In I. Kenesei and C. Pléh (eds.) Approaches to Hungarian 4: The structure of Hungarian. Szeged: JATE. 283-300.

Rebrus, Péter. 2000. Morfofonológiai jelenségek [Morphophonological phenomena]. In Kiefer (2000, 763-947).

Simonyi, Zsigmond. 1907. Igenévi szerkezetek [Non-finite structures]. Budapest: Magyar Tudományos Akadémia.

Surányi, Balázs. 2009a. Adpositional preverbs, chain reduction and phases. In M. den Dikken and R. M. Vago (eds.) Approaches to Hungarian 11: Papers from the New York conference. Amsterdam \& Philadelphia: John Benjamins. 217-250.

Surányi, Balázs. 2009b. "Incorporated" locative adverbials in Hungarian. In K. É. Kiss (ed.) Adverbs and adverbial adjuncts at the interfaces (Interface explorations 20). Berlin \& New York: Mouton de Gruyter. 39-74.

Szabolcsi, Anna. 1994. The noun phrase. In F. Kiefer and K. É. Kiss (eds.) The syntactic structure of Hungarian (Syntax and semantics 27). San Diego \& New York: Academic Press. 179-274.

Tóth, Ildikó. 2000. Inflected infinitives in Hungarian. Doctoral dissertation. Tilburg University.

Tóth, Ildikó. 2011a. A ragozott főnévi igenevek a kései ómagyar korban [Inflected infinitives in Late Old Hungarian]. In M. Bakró-Nagy and T. Forgács (eds.) A nyelvtörténeti kutatások újabb eredményei VI [Recent developments in diachronic linguistic research 6]. Szeged: SzTE. 249-265.

Tóth, Ildikó. 2011b. A -t képzős igeneves szerkezet használata az ómagyarban [On the use of the $-t$ non-finite form in Old Hungarian]. In K. É. Kiss and A. Hegedüs (eds.) Nyelvelmélet és diakrónia [Language theory and diacrony]. Piliscsaba: PPKE BTK. $121-132$. 